\title{
REVIEW
}

\section{The proteins of the surfactant system}

\author{
J. Johansson*, T. Curstedt**, B. Robertson*
}

The proteins of the surfactant system. J. Johansson, T. Curstedt, B. Robertson. CERS Journals Ltd 1994.

ABSTRACT: The structural and functional integrity of pulmonary surfactant depends on several specific proteins. Two of these, SP-A and SP-D, are large and watersoluble, while SP-B and SP-C are small and very hydrophobic. SP-A is an 18-mer of $26 \mathrm{kDa}$ polypeptide chains and contains N-linked oligosaccharides. Structurally, it can be characterized as a collagen/lectin hybrid. Together with SP-B, SP-A is required for conversion of secreted endogenous surfactant to tubular myelin in the alveolar lining. It also regulates surfactant secretion and reuptake of surfactant lipids by type II cells; these functions are probably receptor mediated.

SP-D, a 12-mer of $39 \mathrm{kDa}$ polypeptide chains, is a collagenous glycoprotein with structural similarities to C-type lectins. Both SP-A and SP-D stimulate alveolar macrophages.

SP-B is a 79-residue polypeptide that contains three intrachain disulphide bridges. It exists mainly as a homodimer, which is strongly positively charged and may selectively remove anionic and unsaturated lipid species from the alveolar surface film, thereby increasing surface pressure.

SP-C is a mainly $\alpha$-helical, extraordinarily hydrophobic polypeptide containing 35 amino acid residues and covalently linked palmitoyl groups. Its $\alpha$-helical portion is inserted into surfactant lipid bilayers. SP-C accelerates the adsorption of lipid bilayers to an interfacial monolayer. In babies with respiratory distress syndrome, the clinical response to treatment with surfactant containing SP-B and SP-C is much faster than in babies treated with protein-free synthetic surfactant.

We speculate that, in the near future, surfactant preparations based on recombinant hydrophobic proteins will be available for clinical use. Eur Respir J., 1994, 7, 372-391.
*Dept of Chemistry 1, Karolinska Institutet, Stockholm, Sweden. **Dept of Clinical Chemistry, Karolinska Institutet at Danderyd Hospital, Danderyd, Sweden. 'Dept of Pediatrics, S:t Göran's Hospital, Stockholm, Sweden.

Correspondence: B. Robertson

Research Unit for Experimental Perinatal Pathology

Karolinska Hospital

S-171 76 Stockholm

Sweden

Keywords: Biophysical activity

pulmonary surfactant

replacement therapy

structural analysis

surfactant proteins

Received: July 301993

Accepted for publication August 81993

This work was supported by the Swedish Medical Research Council (project Nos 3351 and 10371), the Swedish Society for Medical Research, Oscar II:s Jubileumsfond, Axel Tielmans Minnesfond and the General Maternity Hospital Foundation.
About 60 yrs ago, von NEERGAARD [1] showed that a substantial part of the resistance to lung expansion is due to alveolar surface tension. However, these results passed without notice until the 1950s, when PATtLE [2] and CLEMENTS [3], independently, rediscovered the presence of a factor which lowered surface tension in the lung. They suggested that the surface active material, surfactant, prevented pulmonary oedema and atelectasis. PATTLE [2] also showed that treatment of the material with trypsin reduced the surface activity, indicating that protein may be an important component of the system. In 1959, AvERY and MEAD [4] showed that respiratory failure in premature infants is due to lack of surfactant. The corresponding disease, which is a major cause of neonatal morbidity and mortality [5], was initially referred to as hyaline membrane disease, from the appearance of dense membranous structures in the collapsed alveoli [6]. Today, this disease is called respiratory distress syndrome (RDS).

Specific treatment of surfactant deficiency goes back to the report by FuJiwara et al. [7], who showed that babies suffering from RDS can be effectively treated by instillation of heterologous surfactant preparations in the airways. Since then, replacement therapy has been widely used in RDS [8]. Phospholipids and hydrophobic proteins are common components of all surfactant preparations from mammalian sources [7,9-11], indicating that these specific surfactant proteins, present in low amounts and initially considered as merely contaminants [12], are essential components of surfactant preparations for replacement therapy. During the last decade, much information about the structure and the functional properties of the surfactant proteins has been obtained.

\section{Physiological role of pulmonary surfactant}

The alveoli are lined by a liquid layer containing surfactant. Without the presence of surfactant, the surface tension would cause the alveoli to collapse, and the main function of the surfactant system is, undoubtedly, to reduce the surface tension at the alveolar air/liquid interface. Under normal conditions, the alveolar surface tension at equilibrium is about $25 \mathrm{mN} \cdot \mathrm{m}^{-1}$. According to theoretical considerations [13], this must be reduced to near $0 \mathrm{mN} \cdot \mathrm{m}^{-1}$ at the end of expiration, in order to oppose the forces created by decreased alveolar radius. Elegant in vivo measurements in rat lung [14] confirmed that the surface tension is reduced to low values at the end of expiration. 
Reduction of surface tension is accomplished by the presence of a monolayer consisting mainly of phospholipids at the air/liquid interface. The hydrophobic acyl chains are oriented towards the air, and the polar head groups interact with the liquid surface. During surface compression, this monolayer forms a rigid structure, consisting mainly of dipalmitoylphosphatidylcholine (DPPC), which reduces the surface tension to near zero. Before the phospholipids reach the monolayer, they are transported between several morphological entities. Surfactant is produced by the alveolar type II cell $[15,16]$, as originally suggested more than 30 yrs ago [17]. The surfactant components are stored intracellularly in dense, multilayered membrane structures, the lamellar bodies [15]. The lamellar body content is excreted into the alveoli, and is there converted [18-20] to a lattice-like structure of tubular lipid doublelayers, called tubular myelin $[21,22]$. Tubular myelin is the main intra-alveolar reservoir of surfactant [23], from which the monolayer at the air/liquid interface is eventually formed [24]. It is possible that the surface film is also formed from other intra-alveolar membrane structures. For formation of these structures and for transitions between them to occur, nonlipid surfactant components, especially the surfactant proteins, are needed $[25,26]$. After use, the surfactant components are constantly removed from the surface film and taken up by the type II cells [27], or degraded by alveolar macrophages [28, 29].

In addition to its ability to reduce surface tension, surfactant interacts with the pulmonary defence system. Surfactant components stimulate phagocytic [30-32], intracellular degradational [33, 34], and migrational [35] capabilities of alveolar macrophages. Furthermore, surfactant components may be directly antibacterial [36], and SP-A (see below) apparently binds with high affinity to a $120 \mathrm{kDa}$ surface glycoprotein of Pneumocystis carinii [37], and to cells infected with herpes simplex virus type 1 [38]. Other studies [39, 40] have suggested that SPA alone enhances phagocytosis, and that it acts specifically on alveolar macrophages. The stimulating effect of SPA on macrophages seems to depend on bacterial species and growth phase [40]. The functional importance in vivo of these findings is unclear. However, because a part of the excreted surfactant material is engulfed by the alveolar macrophages in the removal process, a regulatory role of surfactant in this context is possible. Defective surfactant removal by macrophages is associated with alveolar proteinosis $[41,42]$, a disease in which the alveoli become overfilled with surfactant material. Finally, a depressive effect by pulmonary surfactant on the defence system may also exist, since surfactant material decreases the stimulatory effects of antigens on pulmonary and blood lymphocytes [43, 44]. This activity is associated mainly with the surfactant lipids [44, 45], and may protect the lungs from inappropriate immune reactions.

\section{Composition of surfactant}

The first successful attempts to obtain surfactant material pure enough for chemical characterization were made in the early 1970s [46, 47]. Surfactant from bronchoalveolar lavage fluid, i.e. an unresolved mixture of the material lining the alveolar lumen, is composed of 85-90\% lipids, about $10 \%$ proteins and $2 \%$ carbohydrates [25]. The surfactant lipid composition is essentially the same in several mammalian species [48]. The phospholipids, constituting 80-90\% of the total lipid weight, consist of about $75 \%$ phosphatidylcholine (PC), $10 \%$ phosphatidylglycerol (PG), 5\% phosphatidylethanolamine (PE), 5\% phosphatidylserine (PS) plus phosphatidylinositol (PI), and less than 5\% sphingomyelin. Cholesterol is the dominating neutral lipid, and constitutes $6-8 \%$ of the total lipids. The lipid composition of isolated lamellar bodies is very similar to that of alveolar surfactant [49], but clearly different from that of plasma membranes [50]. Nearly half of the PC content is DPPC, and this molecule, which is the major single component of surfactant, is also the principal surface tension reducing compound [51]. The high percentage of disaturated PC, especially DPPC, in surfactant is unique, as compared to the composition of PC from other sources [52]. Up to about half of the intra-alveolar content of DPPC is present in the monolayer at the air/liquid interface [53]. The content of DPPC in different animal species correlates both with total alveolar surface area [54], and with the ventilatory rate [55].

The existence of hydrophilic surfactant proteins was recognized early [25], but it was not until 1979 that PhizACKerley et al. [56] purified hydrophobic surfactant

Table 1. - Major characteristics of the surfactant-associated proteins

\begin{tabular}{|c|c|c|c|c|}
\hline & $\begin{array}{c}\text { Polypeptide } \\
\text { chain MW } \\
\text { kDa }\end{array}$ & $\begin{array}{l}\text { Quaternary } \\
\text { structure }\end{array}$ & $\begin{array}{l}\text { Special } \\
\text { properties }\end{array}$ & [Ref] \\
\hline SP-A & 26 & 18 -mer & $\begin{array}{l}\text { Glycosylated } \\
\text { collagen/lectin hybrid }\end{array}$ & [57-61] \\
\hline SP-B & 8.7 & dimer & Many basic residues & [62-65] \\
\hline SP-C & 3.7 & monomer & $\begin{array}{l}\text { Very hydrophobic } \\
\text { palmitoylated }\end{array}$ & [65-68] \\
\hline SP-D & 39 & 12-mer(?) & $\begin{array}{l}\text { Glycosylated } \\
\text { collagen/lectin hybrid }\end{array}$ & [69-71] \\
\hline
\end{tabular}

SP: surfactant protein; MW: molecular weight; [Ref]: references. 
proteins from ether/ethanol extracts of porcine surfactant. Four surfactant-specific proteins, with different structural properties, have been identified (table 1). Also, low amounts of serum proteins, such as albumin and immunoglobulin $G$ have been observed in surfactant [47, 72]. The surfactant-specific proteins are called surfactant protein (SP) followed by a letter reflecting their order of discovery [73]. The major surfactant protein, SP-A, and a recently discovered protein, SP-D, are water soluble, while SP-B and SP-C are strictly hydrophobic, requiring organic solvents for solubilization. These two hydrophobic proteins constitute about $1 \%$ of the total surfactant mass [74]. Direct attempts to purify SP-B and/or SP-C or related polypeptides from extrapulmonary sources were unsuccessful [75]. In transgenic mice, using SP-C/diphtheria toxin A or SP-C/chloramphenicol acetyltransferase gene hybrids, SP-C was found not to be expressed in any other major organ than the lung [76, 77], indicating that at least this surfactant protein is lung-specific. This might not be the case for all surfactant proteins, since intestinal brush-border excretes particles, similar in structure to lamellar bodies, and SP-B and SP-D have been identified in this tissue by immunological means [78]. A surfactant protein, probably SP-A, has also been found in the middle ear [79].

\section{Surfactant metabolism}

\section{Synthesis and secretion}

Both surfactant lipids and proteins are produced in the alveolar type II cells [16], which occupy about 5\% of the alveolar surface area [80]. The principal lipid component, DPPC, is produced in the endoplasmic reticulum [16], with glucose as dominating precursor [81]. The palmitoyl groups of DPPC originate mainly from palmitoylcoenzyme A [82]. The lipids are transferred from the endoplasmic reticulum via the Golgi complex to the lamellar bodies, and finally appear in intra-alveolar tubular myelin [16]. Surfactant proteins are also produced in the endoplasmic reticulum, but they are transferred to the lamellar bodies via so-called multivesicular bodies [16]. A similar picture of the protein routing has emerged from immunological studies with antibodies directed to SP-A [29, 83-85], or SP-B [86, 87]. The lamellar bodies contain both SP-A [84, 85, 88], and hydrophobic proteins $[56,89,90]$, but not SP-D [91]. In contrast to alveolar surfactant, where SP-A is the major protein, the lamellar bodies seem to contain mainly SP-B and SP-C [90], indicating that a relatively small amount of secreted SP$\mathrm{A}$ is released with lamellar bodies [92]. The explanation for this is not known, but it might be related to the supposed intra-alveolar functions of the proteins ( $c f$. below). Thus, the lamellar body is apparently the site of fusion of surfactant lipid and protein components. The reasons for the apparently divergent intracellular routes for the surfactant lipid and protein components are unknown. There is immunocytochemical evidence that SP-A [84, 85], and SP-B [93] are also synthesized in nonciliated bronchiolar cells, i.e. Clara cells. Whether this synthesis contributes significant amounts of surfactant protein to the alveolar surfactant system is not known.

Excretion of surfactant components is accomplished by exocytosis of the lamellar body content [18]. Both synthesis and excretion of surfactant is regulated by several compounds. However, synthesis and secretion are probably independently regulated processes [94]. Increased ventilation augments surfactant secretion, and the effect is apparently mediated by acetylcholine [95], $\beta$-adrenergic agents [96], and prostaglandins [96]. Furthermore, $\beta$-adrenergic compounds have been reported to increase the excretion of surfactant via cyclic adenosine monophosphate (cAMP)-dependent processes [97], protein kinase C-mediated mechanisms [98], leukotrienes [99, 100], and increased intracellular $\mathrm{Ca}^{2+}$ levels [101]. Perhaps of greater interest is that this process seems to be regulated in a feed-back fashion, since SP-A has been observed to inhibit surfactant secretion [102, 103]. For inhibition to occur, SP-A must bind to a high affinity site on type II cells. This binding requires $\mathrm{Ca}^{2+}$ [104], but the carbohydrate moieties of SP-A ( $c f$. below) are not needed [105, 106]. Also, lectins other than SP-A have been shown to inhibit phospholipid secretion from type II cells [107].

Actin filaments are present in human bronchoalveolar lavage [108], and have been shown to be involved in the movement and exocytosis of lamellar bodies [109]. Such actin-dependent mechanisms might be under regulatory control, since in type II cells actin is phosphorylated by a cAMP-dependent mechanism [110].

\section{Regulation of surfactant protein synthesis}

The synthesis of surfactant proteins is both developmentally and multihormonally regulated [111-113]. SP-B and SP$\mathrm{C}$ seem to be expressed at an earlier stage of gestation than SP-A. Messenger ribonucleic acids (mRNA) for human SP-B and SP-C are detected from the second trimester [114], whereas, from the third trimester the levels of SP-A mRNA [115] and protein [116] increase in parallel with the surfactant phospholipids. Interestingly, the formation of lamellar bodies precedes the expression of SP-A in mouse embryos [117]. The intracellular processing and secretion of SP-A is dependent on proline hydroxylation, but not on addition of $\mathrm{N}$-linked carbohydrate [118]. Furthermore, SP-B and SP-C are probably independently regulated, since there is no obvious relationship between their respective mRNA levels in individual lungs [114].

The hormonal regulation of the surfactant proteins is complex. SP-B and SP-C levels in foetal cell cultures are increased after exposure to glucocorticoids [114, 119, 120]. However, induction of SP-B is reported to include an increase in both transcription rate and mRNA stability, whilst induction of SP-C requires ongoing protein synthesis, involving an increase in the rate of gene transcription, with no change in mRNA stability [120]. SP-A synthesis has been reported to be both stimulated [115], and inhibited [121, 122], by glucocorticoids. The explanation to this apparent inconsistency is probably that SP-A exhibits a 
biphasic, dose-dependent response to glucocorticoid treatment [123, 124], where the stimulatory and inhibitory effects are due to increased transcription and reduced mRNA stability, respectively [125]. Furthermore, in an adenocarcinoma cell-line, glucocorticoid enhanced pro SP-B expression, whilst the expression of SP-A was reduced [126]. Also, cAMP takes part in the regulation of surfactant protein synthesis. In foetal rabbit lung, SPA mRNA was increased by a cAMP analogue via a protein factor [127], and there are indications that the effects of glucocorticoids and cAMP, at least on SP-A and SP-B, are additive [123, 128]. Finally, epidermal growth factor increases, and transforming growth factor$\beta$ decreases, the synthesis of SP-A [129].

\section{Intra-alveolar metabolism}

During each inspiration, spreading of phospholipids from tubular myelin (or other intra-alveolar membrane structures) to the monolayer at the air/liquid interface has to occur in less than $1 \mathrm{~s}$, in order to cover the expanding liquid surface. Although the directly surface active monolayer consists mostly of DPPC, several other surfactant components seem to be of vital importance. The importance of the surfactant proteins in this context will be discussed below, in light of their structural properties.

The surfactant phospholipid composition, as such, is of importance for rapid adsorption of the monolayer. Unsaturated PC and PG lower the solid to liquid transition temperature of the lipids below body temperature, and thereby facilitate the spreading from tubular myelin to the monolayer. Furthermore, PG and other negatively charged phospholipids may be important for "spontaneous" disruption of those lipid bilayers that touch the air/liquid interface [130]. The surface film first appearing after spreading of the lipids, containing unsaturated species for increased fluidity, is probably refined by physical squeezing out of unsaturated phospholipids, leaving only a stiff DPPC layer behind $[131,132]$. YU and POSSMAYER [133] and Mathialagan and Possmayer [134] reported that the removal of $\mathrm{PG}$ from the monolayer is facilitated by SP-B, and may be further enhanced by SP-A in the presence of SP-B. SP-C did not seem to have any major impact on the refinement process.

The monolayer, presumably after refinement, has a turnover time of 3-11 h [135]. Surfactant lipids [28], and proteins $[29,85,86]$ are both removed by alveolar macrophages. However, a more important route of removal [27] and reutilization [136] of surfactant is reuptake by the type II cells. SP-C is removed from the alveoli at a faster rate than PC [137, 138]. Several investigations indicate that surfactant lipids at least are recycled between lamellar bodies and the alveoli [135, $139,140]$, although not to the same extent for all lipid species [141-143]. Whether the phospholipids are reutilized as intact molecules, or degraded and used in de novo synthesis is unclear [81]. What signals, if any, direct the surfactant components to macrophages or type II cells are not known, but some clues to this riddle have been obtained. Lectins bind to [144] and are taken up by type
II cells, and transferred to lamellar bodies [145]. This implies that the lectin-like SP-A and SP-D may stimulate surfactant reuptake. In fact, SP-A has been observed to enhance surfactant uptake by type II cells, and protect PC from degradation [146, 147], and also other, nonsurfactant lectins can stimulate PC uptake by type II cells [148]. SP-A is probably internalized by type II cells via receptormediated endocytosis [149]. Thus, the regulation of surfactant turnover might involve multiple receptordependent functions of SP-A, since it both decreases secretion ( $c f$. above), and stimulates reuptake of surfactant components. The higher content of SP-A than SP-B/SP$\mathrm{C}$ in alveoli, and the opposite relationship in lamellar bodies, might be due to a longer intra-alveolar lifetime of SP-A than of the hydrophobic surfactant polypeptides [90], or different secretion pathways for surfactant proteins [92].

A hydrophobic ether/ethanol soluble surfactant protein has been claimed to stimulate the uptake of liposomal phospholipids by type II cells [150]. A negative linkage between synthesis and reuptake might, therefore, exist as a hydrophobic protein inhibits phospholipid synthesis in type II cells [151]. The increased uptake caused by the hydrophobic protein could, however, be entirely accounted for by phospholipid components in the protein fraction [152]. Furthermore, SP-B and SP-C increased the uptake of PC in both type II cells and lung fibroblasts by nonreceptor mediated mechanisms, whilst SP-A specifically enhanced the uptake by type II cells [153].

\section{Structure and molecular biology of surfactant proteins}

\section{Hydrophilic proteins}

SP-A is the most abundant surfactant protein in the alveoli, constituting about $50 \%$ of the total surfactant protein [154, 155]. It actually constitutes a family of molecules with both different sizes $(26-38 \mathrm{kDa}$ in the reduced state) [155-163], and different charges (isoelectric points $\mathrm{pH} 4-5)$ [72, 159, 164]. The differences are due to a multitude of post-translational modifications. SP-A has been reported to be modified via $\mathrm{N}$-linked glycosylation [159, 165], sialylation [72, 158, 162, 164], acetylation [57, 166], sulphation [167], hydroxylation [168], and also by vitamin K-dependent carboxylation of glutamic acid (Glu) residues [169]. However, the proposed presence of $\gamma$-carboxyglutamic acid in SP-A has been challenged in other reports $[170,171]$. The amino acid sequence of the polypeptide chain from human [57, 58], canine [59], rat [60], and rabbit [172] origins has been deduced from the corresponding complementary deoxyribonucleic acid (cDNA) sequences. The primary translation product is a 247-248 residue-long polypeptide, depending on species, and containing a 20 residue-long signal peptide. The corresponding human gene has been localized to chromosome 10 [173, 174].

Structurally, the SP-A polypeptide chain consists of two different sections. The $\mathrm{N}$-terminal portion is sensitive 
to collagenase treatment [165], and has a collagen-like amino acid sequence [58-60, 160, 172], with repeating glycine (Gly)-X-Y triplets (where $\mathrm{X}$ and $\mathrm{Y}$ are any amino acid residues), and a high content of hydroxyproline. This collagen-like domain has been claimed to be important for interactions between SP-A and phospholipids [175]. The C-terminal domain, on the other hand, is collagenaseresistant [176], and exhibits structural [177], and functional $[178,179]$ resemblance to lectins. The C-terminal domain, furthermore, contains two intrachain disulphide bridges $[180,181]$, and the asparagine (Asn) residue that binds carbohydrate. Protein isolated from patients with alveolar proteinosis consists mainly of oligomeric forms of SPA $[182,183]$, at least partly formed by interchain disulphides between the C-terminal domains [183]. This indicates that interchain disulphide bridges can occur in this domain, at least in this disease state. A mannose binding protein, also a lectin, from rat liver has a similar molecular architecture, and exhibits structural homology to SP-A [178]. The exon structures and the chromosome localization of the human mannose binding protein gene and the SP-A gene are also similar [184]. Mannose binding protein specifically recognizes bacterial oligosaccharides $[185,186]$, and the structural resemblance between SP$\mathrm{A}$ and mannose binding protein, thus, further strengthens the probability that SP-A plays a role in host defence mechanisms.

In its native state, SP-A is arranged as a hexamer, with subunits consisting of trimers of polypeptide chains [61], thus, in total forming an 18-mer. The six trimeric molecules are held together by the N-terminal, collagenlike parts, that are arranged in a disulphide-dependent [59, 176], and triple helical [187], fashion. Six triple helices are, thus, held together in a stem, whilst the Cterminal parts are arranged like a floral bouquet (fig. 1) $[61,180,188]$, similar to the structure of complement factor C1q [32]. Minor residue heterogeneities between the different SP-A polypeptide chains in a trimer are necessary for further polymerization to occur [189]. By using deletion mutants, SPISSINGER et al. [190] studied the influence of the collagenous and lectin-like part, respectively, on the folding and secretion of SP-A in SV40 transformed simian (COS) cells. Apparently, the lectin part folded correctly on its own, i.e. without the presence of the collagenous part, whilst the isolated collagenous part did not fold properly. This might indicate that trimers of the lectin part serve as folding nucleation sites, and that the folding then proceeds in a C-terminal to N-terminal direction [190]. The three-dimensional structure of the lectin part of the mannose binding protein has been determined by X-ray crystallography [191], and it indicates that each monomer might contribute one face of the carbohydrate binding site, and that the trimeric structure is, thus, necessary to accommodate high affinity binding. This structure is probably also grossly valid for the SP-A lectin part, considering their similar amino acid sequences.

A protein with a molecular mass of about $10 \mathrm{kDa}$, immunologically related to SP-A, has been observed [192]. This polypeptide is probably identical to a hydrophobic but ether/ethanol insoluble fragment isolated by KING and co-workers [47]. The genesis of this fragment is not clear, but it might be a metabolic product of SPA [193, 194].

Recently, another hydrophilic surfactant protein, SP$\mathrm{D}$, has been identified. It is synthesized by isolated rat type II pulmonary cells $[69,195]$, but has also been found in Clara cells [91, 195, 196], and alveolar macrophages [91]. SP-D is also present in rat bronchoalveolar lavage [197], and human amniotic fluid [70]. However, lamellar bodies do not contain SP-D [91]. The native molecule is probably made up of four subunits, each of them composed of three apparently identical disulphide-linked glycosylated polypeptides of about $43 \mathrm{kDa}$ in molecular mass $[69,70]$. The amino acid sequence, deduced from the human [70], and rat [71], cDNA sequence, indicates that the SP-D polypeptide is 355 residues long, with a short N-terminal section of 25 residues, followed by a
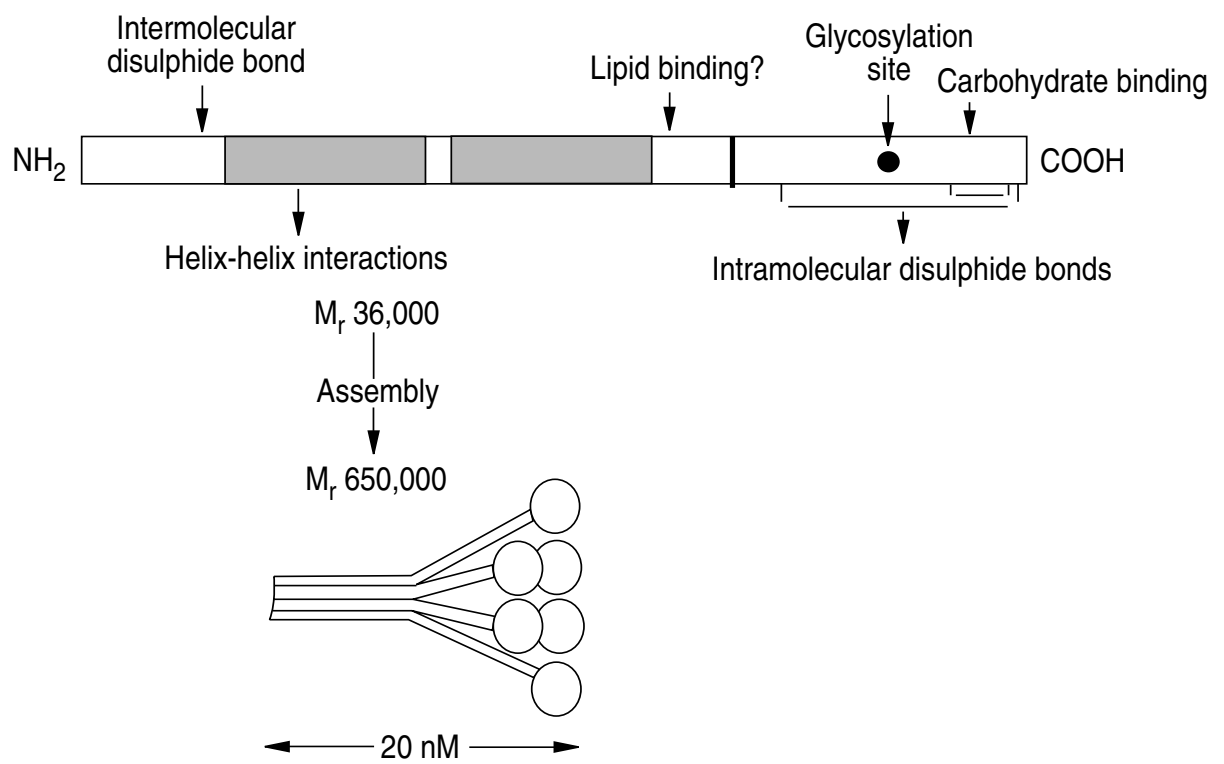

Fig. 1. - Diagrammatic representation of surfactant protein A (SP-A) linear domain structure and assembly into the native 18-meric form. (From [188] with permission). 
collagen-like region of 177 residues, and a C-terminal C-type lectin domain of 153 residues. SP-D exhibits considerable sequence similarity to the C-type lectins. Thus, human, rat and bovine SP-D show more than $60 \%$ identity in sequence with bovine conglutinin [70, 71, 198]. Furthermore, a newly identified bovine serum lectin (CL-43) also has structural similarities to bovine conglutinin and SP-D [199]. The human gene for SP$\mathrm{D}$ is localized to the long arm of chromosome 10, close to the genes for two other C-type lectins, SP-A and mannose-binding protein [200]. SP-D apparently does not contribute to the surface active properties of pulmonary surfactant [201]. The protein is probably not important for the structural organization of the surfactant phospholipids, since SP-A and SP-D distribute differently in rat bronchoalveolar lavage fluid [202]. However, SP-D is co-purified with lipids [202], and binds PI specifically and in a $\mathrm{Ca}^{2+}$-dependent manner [203, 204]. The functional properties of SP-D in the surfactant system have not been fully elucidated, but rat SP-D enhances the production of oxygen radicals by alveolar macrophages, and may play a role in the host-defence system of the lung [205].

\section{Hydrophobic proteins}

PhizaCKerley et al. [56] first described the presence of protein in organic solvent extracts both of extracellular surfactant and lamellar bodies. These proteins, constituting only a minor part of the surfactant content, have unusual properties, which make them very difficult to purify and characterize. In fact, even the mere existence of surfactant lipoproteins has been denied, after serious but unsuccessful attempts to purify them [206]. Initially, this resulted in a low interest in the hydrophobic surfactant proteins, compared to the more abundant and water-soluble SPA. However, when it was realized that the hydrophobic proteins are vital components of surfactant preparations for replacement therapy, they received considerable attention. Since then, it has been shown for several species that pulmonary surfactant contains at least two waterinsoluble proteins [74, 207, 208], designated SP-B and SP-C. Together they constitute $1-2 \%$ of the surfactant weight, and the SP-B/SP-C molar ratio is about 1:2 [74]. Estimates of the molecular masses of SP-B and SP-C by sodium dodecyl sulphate-polyacrylamide gel electrophoresis (SDS-PAGE) have given varying results, probably due to heterogeneous preparations, and to the great hydrophobicity of the proteins. Values of $15-18 \mathrm{kDa}$ and about $7 \mathrm{kDa}$ have been obtained for SP-B in nonreduced and reduced form, respectively [207-209]. Larger, disulphide-dependent polymers of SP-B, with molecular masses of about 20 and $26 \mathrm{kDa}$, have also been observed [210]. The corresponding values observed for SP-C are about $10 \mathrm{kDa}$ (nonreduced) and about $5 \mathrm{kDa}$ (reduced) [207-209].

Characterization of the airway proteins, SP-B and SP$\mathrm{C}$ was hampered for a long time, mainly because of unusual properties of the polypeptides. Incomplete amino acid sequences of bovine SP-C [208, 211-213], bovine
SP-B [208, 212, 213], and porcine SP-B and SP-C [74], have been published. For successful determination of primary structures and post-translational modifications of SP-B and SP-C they had to be purified to apparent homogeneity. Several approaches to the purification of the hydrophobic surfactant proteins have been described [74, 207, 210, 211, 214-219]. CURStedt et al. [74] introduced repeated chromatography of the surfactant phospholipid fraction on Sephadex LH-60 in chloroform/ methanol, 1:1 (v/v), containing 5\% $0.1 \mathrm{M} \mathrm{HCl}$. By this procedure, removal of phospholipids and separation of the two hydrophobic surfactant proteins were achieved, resulting in apparently homogeneous fractions of SP-B and SP-C.

Sequence analysis revealed that SP-B is a 79-residue polypeptide, with an exact molecular mass of $8.7 \mathrm{kDa}$ [62]. SP-B is, furthermore, a disulphide-dependent homodimer, and the cysteine residue responsible for dimerization, as well as the intrachain disulphides have been determined for human and porcine SP-B (fig. 2) [63, 64]. Somewhat unexpectedly from its hydrophobic nature, SP-B exhibits a fairly conventional primary structure, with all types of amino acid residues represented, absence of covalently linked fatty acyl groups [65], and with no extremely hydrophobic segment, except for short stretches of hydrophobic residues at positions 37-42 and 54-58. However, the monomer is probably tightly folded, due to the three intrachain disulphide bridges that connect distant parts of the polypeptide chain, and overall there is an excess of aliphatic residues in SP-B. These features may explain its hydrophobic properties.

SP-C contains, dependent on species, 33-35 amino acid residues [66-68], and two juxtapositioned cysteines in the N-terminal part contain one thioester-linked palmitoyl group each (fig. 3) [65]. The total molecular mass of $\mathrm{SP}-\mathrm{C}$ is $4.2 \mathrm{kDa}$. Canine SP-C has only one palmitoylcysteine, the second one being replaced by phenylalanine [68]. The SP-C polypeptide sequence is highly unusual, lacking, dependent on species, $8-10$ of the 20 common types of amino acid residues. Between positions 13 and 28 , it contains only aliphatic branched-chain residues (i.e. valine, leucine or isoleucine) and up to seven consecutive valines (fig. 3). This extremely hydrophobic part of the molecule is highly conserved between the species analysed. On the other hand, the N-terminal third of the molecule exhibits some hydrophilicity, having two or three positively charged residues, and also varies between species. This gives the polypeptide chain a detergent-like appearance. However, this overall arrangement is less obvious, considering the entire molecule, since the thioester-linked palmitoyl groups are bound to the $\mathrm{N}$-terminal part, making this part of the molecule hydrophobic also.

Both SP-B and SP-C have also been studied at the cDNA level. Such analyses have revealed that the airway proteins must be derived from larger precursor forms, that are apparently not present in the alveoli. Thus, SP$\mathrm{B}$ is derived from a $40-42 \mathrm{kDa}$ precursor [219-223], pro SP-B (fig. 2), that contains one conserved signal for $\mathrm{N}$-linked glycosylation in the C-terminal region. It is probable that pro SP-B is actually glycosylated, because it is sensitive to endoglycosidase $F$ treatment [119, 224]. 
pro-SP-B

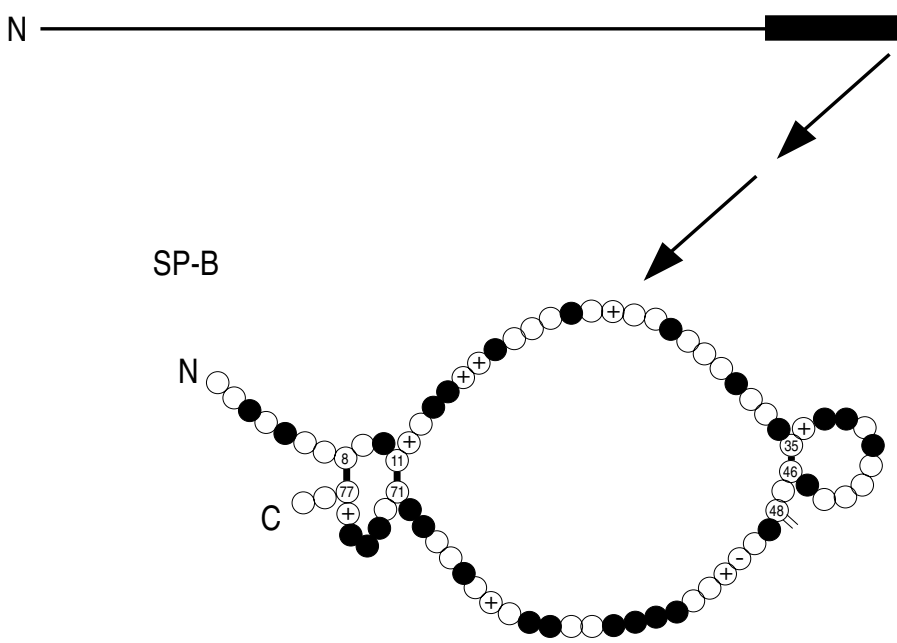

Fig. 2. - Schematic presentation of the surfactant protein B (SP-B) covalent structure and the processing of pro SP-B to SP-B. The thick line in pro SP-B represents the SP-B portion. In SP-B each circle represents one amino acid. Black circles symbolize aliphatic, branched-chain residues; circles with a plus or a minus sign represent residues with basic and acidic side chains, respectively. Filled lines connecting numbered residues symbolize intrachain disulphide bridges, and the open line from cysteine 48 represents the interchain disulphide that links two polypeptide chains into a homodimer.

In an adenocarcinoma cell-line, pro SP-B was processed in several steps, as observed by SDS-PAGE analysis [225]. Firstly a leader-like N-terminal peptide was removed, followed by apparent cleavage of pro SP-B in the vicinity of the residue corresponding to the SP-B $\mathrm{N}$-terminus. Further processing was not observed, and the intra- or extracellular location of the processing was not clarified. SP-C, likewise, emanates from a $20 \mathrm{kDa}$ proform [226-228], pro SP-C (fig. 3), lacking potential glycosylation sites. In contrast to pro SP-B, pro SP-C lacks an N-terminal signal sequence, but the internal SP$\mathrm{C}$ part, as such, has been shown to be important for directing pro SP-C to lipid bilayers; and pro SP-C behaves as a type II transmembrane protein [229]. The SP-B gene is localized to chromosome 2 [230, 231], while two SP-C genes are situated on chromosome 8 [232, 233].

\section{pro SP-C}
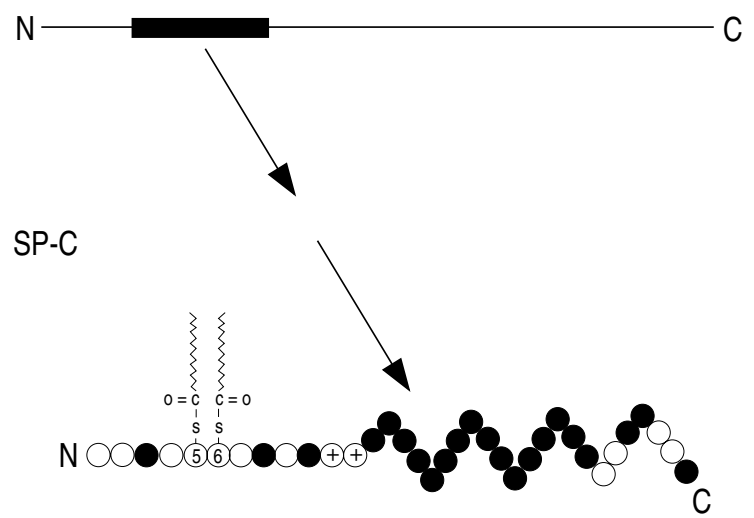

Fig. 3. - Illustration of the processing of pro SP-C to SP-C, and the SP-C structure. Symbols are analogous to those used in figure 2. Cysteines 5 and 6 each have one thioester-linked palmitoyl group. SP: surfactant protein.
Preparations of both SP-B and SP-C exhibit truncated polypeptides, lacking 1 or 2 of the $\mathrm{N}$-terminal residues compared to the longest form $[62,65-68]$. The ratio of the different truncated forms is 10 to $30 \%$ of the fulllength forms, and varies both between animal species and between adult and foetal forms of human SP-C [67]. The biological significance of $\mathrm{N}$-terminal truncations in general is unknown, but it appears to occur in widely different proteins, and to varying extent [234]. Since both SP-B and SP-C are probably derived from the corresponding proforms by proteolysis, the truncated forms may be due to low specificity of the liberating enzyme(s). Later aminopeptidase-like activity cannot, however, be ruled out as a cause for the truncated polypeptides. Artifactual origin seem less probable, because of constant occurrence and species-dependent pattern. Some internal positions in both SP-B and SP-C exhibit polymorphism [62-64, 67]. The explanation behind this phenomenon is not obvious. However, two human genes for SP-C have been identified [232], but only one for human SP-B [231]. Both for the N-terminal truncations and for the internal residue polymorphism, it is difficult to visualize any major structural deviation between the different forms and, therefore, the corresponding functional implications are probably minor, if any.

The overall secondary structures of SP-B and SP-C, solubilized in phospholipid bilayers containing DPPC and PG as major components, have been determined using Fourier transform infra-red spectroscopy [235-238]. SP-B contains about 27-45\% $\alpha$-helical structures [237-239], and about $22 \% \beta$-sheets [237]. The $\alpha$-helices interact preferentially with superficial parts of the lipid bilayers, and the basic residues of SP-B (fig. 3) are thought to be important due to interaction with anionic phospholipids [237]. SP-C is predominantly $\alpha$-helical. The reported $\alpha$-helical content of SP-C, however, varies between $46 \%$ [238], and 90\% [236]. This difference is probably not caused by the fact that SP-C of different origin was used 
(bovine and porcine, respectively), but may be due to the fact that, in the study by VANDENBUSSCHE et al. [236], the SP-C/phospholipid mixtures were centrifuged over a sucrose gradient before analysis. This might remove non- $\alpha$-helical forms of SP-C, thereby explaining the higher $\alpha$-helical content obtained. In agreement with this, Pastrana et al. [235] also found that at higher SP$\mathrm{C}$ concentrations $(1.5 \mathrm{~mol} \%) \beta$-sheet structures were formed. This was interpreted to be a result of peptide aggregation. In the phospholipid bilayers, the $\alpha$-helix region of SP-C is oriented parallel to the lipid acyl chains [235, 236], strongly indicating that the hydrophobic part of SP-C is transmembranous. Interestingly, removal of the palmitoyl groups of SP-C, apparently, also reduces the $\alpha$-helical content significantly when the polypeptide is incorporated into phospholipid bilayers [236].

In conclusion, in spite of their overall hydrophobic nature, SP-B and SP-C are structurally entirely different. The polypeptide chains differ in length and their amino acid sequences are unrelated. The post-translational modification of each polypeptide is also unique, as well as the secondary and quaternary structures of the molecules. The amino acid sequences surrounding the sites necessary to cleave in pro SP-B and pro SP-C to generate the mature airway peptides are also unrelated, indicating that generation of SP-B and SP-C from the corresponding proforms is carried out by different enzymes. The structural differences between SP-B and SP-C, of course, make it tempting to speculate that they fulfil quite separate functions in the surfactant system.

\section{Functional correlations}

SP-A, SP-B and SP-C are all present in alveolar surfactant. However, only the hydrophobic surfactant polypeptides, SP-B and SP-C, appear to be essential components in surfactant preparations for replacement therapy (see below), indicating that they have unique functional roles in the formation of the surface active monolayer. Surfactant proteins are required both for the transition between lamellar bodies and tubular myelin, and for the spreading of tubular myelin components to the surface film. Besides lipids extracted from pulmonary surfactant, SP-A and calcium ions are essential for the transition between lamellar bodies and tubular myelin [240-244]. Particles structurally similar to tubular myelin can also be formed by recombining SP-A, SP-B and calcium ions with a mixture of DPPC and PG [245, 246]. Thus, all results indicate that both SP-A and SP-B are essential proteins in the formation of tubular myelin. SP-A has been shown to bind specifically 2-3 $\mathrm{Ca}^{2+}$ per molecule [171]. An attractive explanation for the requirement of both SP-A and calcium is that $\mathrm{Ca}^{2+}$ neutralizes SP-A carboxylate ions at physiological $\mathrm{pH}$ [244].

Although observations clearly indicate specific functions for SP-A in the surfactant system, it seems that SP-A is not required for the creation of the surface active monolayer. Hence, a surfactant preparation containing only lipids and $1 \%$ of proteins soluble in organic solvents exhibited surface properties similar to those of natural surfactant
[247]. SP-B and/or SP-C, in contrast to SP-A, are required for a rapid adsorption of phospholipids to an air/liquid interface [74, 133, 207, 214-216, 239, 248, 249]. Apparently, both SP-B and SP-C are required for optimal activity, but after addition of either SP-B or SP-C to phospholipids, surface properties that are superior to those of phospholipids alone have been observed [74, 133]. There is also evidence for a co-operative function of the hydrophilic and hydrophobic surfactant proteins in the formation of a surface active monolayer [219, 250]. In a model system, the presence of SP-B and SP-C in the interphase phospholipid monolayer further accelerates the adsorption of additional phospholipids from the subphase [251]. This effect occurs independently of lipid class, but is dependent on the protein concentration, and SP-B seems to be more effective than SP-C in this respect [251, 252]. Furthermore, a monoclonal antibody directed against SP-B [89] inhibited rapid adsorption of surface active material and caused increased surface tension in vitro [86]. Mice inoculated with hybridomas producing the antibody developed severe pulmonary damage [253, 254], and neonatal respiratory distress could be induced by instilling the anti-SP-B antibody into the airways of newborn rabbits [255]. None of these effects could be obtained with nonspecific immune sera, indicating that the hydrophobic surfactant proteins, at least SP-B, carry out essential functions in the surfactant system.

Synthetic peptides corresponding to some parts of native SP-B, when associated with phospholipids, possess some biophysical and biological activity [239, 256-260], but are clearly inferior to native SP-B in both respects. Also, synthetic peptides with simplified sequences designed to mimic specific parts of the SP-B polypeptide [258, 260], and amphipathic $\alpha$-helical peptides based on SP-A [261], exhibit some surface activity in combination with phospholipids. However, although encouraging, such results should perhaps be taken somewhat cautiously, since an amphipathic $\alpha$-helical decapeptide with a sequence unrelated to SP-B [262], or simple amino acid homopolymers [263] combined with phospholipids also exhibit biophysical activities that are superior to phospholipids alone, but inferior to natural pulmonary surfactant.

Plasma proteins leaking into the airspaces inhibit surfactant and raise the alveolar surface tension, a mechanism that might be of pathophysiological importance in adult respiratory distress syndrome (ARDS) [264]. Fibrin monomer is a particularily potent inhibitor [265]. SP-A has been shown to reverse such an inhibition of surfactant caused by an excess of plasma proteins in the alveoli [266], whilst a recombinant SP-C polypeptide (i.e. lacking the covalently linked palmitoyl groups) seems to be less effective in this respect [267]. However, the palmitoyl groups of SP-C (fig. 3) and/or other additional factors are probably important in this context, since an organic-solvent extract of surfactant used for replacement therapy is more resistant to inhibition than a synthetic mixture of phospholipids and hydrophobic proteins [267], and since natural surfactant in high concentration is almost resistant to inhibition by albumin [268]. The overall structural and functional implications of the palmitoyl 
groups in SP-C are, however, incompletely understood. SP-C is soluble only in organic solvents even after release of the palmitoyl groups. This is in contrast to several other palmitoylated proteins, where the palmitoyl groups are linked to an otherwise hydrophilic polypeptide chain [269-271]. However, depalmitoylated SP-C and synthetic SP-C without palmitoyl groups are much more difficult to handle than the intact molecule, probably, at least partly, because of formation of oligomeric forms. The disulphide-dependent dimeric forms of SP-C observed upon SDS-PAGE [207-209, 238], may be artifacts formed by inadvertent cleavage of the thioester linkages and subsequent formation of intermolecular disulphides. However, BAATZ et al. [238] reported that about 15-20\% of bovine SP-C is probably a true dimer. In a model membrane containing DPPC/egg PG/palmitic acid (PA) 68:22:9 (by weight) dimeric SP-C seems to be located in a hydrophobic environment, exhibiting almost exclusively $\beta$-sheet structures [238]. The different properties of monomers and oligomers might indicate that the palmitoyl moieties serve as thiol-blocking groups, thereby preventing oligomerization. This is compatible with the facts that canine SP-C only has one palmitoylated cysteine (Cys) [68], and that the molar ratio between palmitoyl groups and Cys residues is close to 1.0 in all species analysed. However, removal of the palmitoyl groups causes conformational changes of the polypeptide chain, without apparent aggregation [236]. There is no support for other fatty acyl groups thioester-linked to SP-C than palmitoyl groups $[65,68]$, indicating that palmitoyl moieties are of special importance. This suggests that this modification fulfils other functional properties than blocking free - $\mathrm{SH}$ groups. Palmitoylation/depalmitoylation has, for example, in another context, been suggested to regulate protein activity [272], perhaps in a manner similar to phosphorylation/dephosphorylation, and protein bound palmitoyl groups apparently have a significantly faster turnover rate than the protein itself [273]. Furthermore, in SP-C the sequence flanking the Cys residue(s) is remarkable, and conserved in all species so far studied. In particular, the proline (Pro) residue next to each Cys might be of importance due to its ability to prevent rotation of the polypeptide backbone. These facts strongly indicate that the thioesterlinked palmitoyl groups have a specific impact on the structural and functional properties of SP-C.

Lamellar bodies contain different enzymes [274, 275], but palmitoylation of SP-C probably occurs at an earlier stage, although the exact location is unknown. The intracellular location(s) of the enzyme(s) that process pro SP$\mathrm{C}$ to SP-C is not known either. Hence, it is possible that pro SP-C already is palmitoylated. This is attractive from a functional point of view, since pro SP-C is hydrophilic, except for the SP-C part [227]. Thus, palmitoylation of pro SP-C could be a means of associating the molecule with surfactant lipids before proteolytic generation of SP$\mathrm{C}$ occurs. Although there is no obvious amino acid similarity in the region surrounding palmitoylated cysteines in general [276], the absence of a conserved segment in SP-C that can easily be interpreted as a recognition signal for palmitoylation $[65,68]$ also favours the concept that the palmitoyl groups are attached to pro SP-C.
The functions of the surfactant proteins at a molecular level are not known. A spectroscopic study [277] indicated that a high concentration of SP-A induces ordering in a mixture of DPPC/dipalmitoyl/phosphatidylglycerol (DPPG), 85:15 (w/w). Such actions are more compatible with a function of SP-A in the packing of phospholipids and/or surfactant reuptake into type II cells, than in the facilitation of rapid surface adsorption of lipid components. The same study showed that an undefined mixture of surfactant proteins other than SP-A induced disordering of the lipids, and SHIFFER et al. [278] showed that an unresolved mixture of the hydrophobic surfactant proteins increased permeability of lipid vesicles and caused fusion of liposomes. These effects were increased by the simultaneous presence of $\mathrm{Ca}^{2+}$ and PG. Other biophysical measurements [279], although not conclusive, suggested that SP-C might increase lipid adsorption, by inducing the formation of non-bilayer lipid structures. Using fluorescent phospholipid probes, HorowITZ et al. [280] found that SP-C orders the bilayer surface, but disrupts the interior acyl chain packing. The latter effect may be of importance for the rapid spreading of phospholipids from bilayer structures to the interphase monolayer, while the former effect might be of importance for stabilizing the interphase monolayer once it is formed.

It is possible to correlate some of the supposed molecular mechanisms of SP-B and SP-C with their covalent structures. Both SP-B and SP-C, in contrast to the negatively charged SP-A, have an excess of positive charges. SP-B has a great excess of basic residues, which are spread over almost the entire polypeptide chain (fig. 2). It is, therefore, probably capable of making several strong electrostatic interactions with anionic phospholipids, of which PG is predominant in surfactant. A structural model has been proposed [237], whereby SP-B associates with phospholipid bilayers by a combination of electrostatic interactions between polypeptide basic side-chains and anionic phospholipids, and hydrophobic interactions between polypeptide hydrophobic $\alpha$-helices and lipid acyl chains. The suggested structural relationship between SP-B and the kringle structure of complex serine proteases [63] also indicates that SP-B has binding functions, since some kringles can bind to phospholipids. Interestingly, SP-B cooperates with PG in the rapid spreading of the phospholipid film, and it might also participate in the refinement of the monolayer by removing PG species. A fluorescence anisotropy study [281] indicated that SP$\mathrm{B}$ might indeed interact selectively with PG to yield a more ordered bilayer surface.

The high degree of conservation of pro SP-B outside the SP-B portion [222] may indicate that the proform and/or other proteolytic fragments than SP-B are also functionally important. The observed relationship between pro SP-B and prosaposin [282] suggests defined functional roles for pro SP-B, possibly in the surfactant system, in addition to serving as a precursor to SP-B. Prosaposins are, like pro SP-B, proteolytically processed to smaller fragments [282], and there are indications that serine protease-activity is also required for the metabolism of alveolar surfactant, since $\alpha_{1}$-antitrypsin inhibits the conversion of tubular myelin to vesicular forms of surfactant, 
while inhibitors of metallo-, thio-, and acid proteases exhibited no inhibitory effect [283]. The corresponding enzyme has been purified [284]. However, pro SP-B or any other fragments of it than SP-B have not yet been shown to be present in the alveoli, and whether pro SP$\mathrm{B}$ actually gives rise to other biologically active fragments than SP-B has not yet been studied.

SP-C has a net positive charge at physiological $\mathrm{pH}$ because of two juxtapositioned and conserved basic residues (fig. 3). However, the clearly outstanding structural feature of SP-C is the extremely hydrophobic middle/ C-terminal segment, which lacks known counterparts. The hydrophobic segment is certainly long enough to interact with PC liposomes [285], and provided that the $\alpha$-helical components observed [235, 236] represent one continuous straight $\alpha$-helix, it will be capable of spanning the width of a lipid bilayer. Thus, the present picture is that the hydrophobic, $\alpha$-helical middle/C-terminal part of SP-C interacts with the hydrocarbon tails of the phospholipids in the interior part of a surfactant lipid bilayer, while the somewhat hydrophilic N-terminal polypeptide part, especially its charged groups, interacts with the polar phospholipid head groups. Whether the palmitoyl groups interact with the same bilayer as the polypeptide chain, or cross-link different bilayer entities, is unknown. Such interactions might destabilize the bilayers, and thereby facilitate their disruption. Once the conversion of bilayers to monolayers at the air/liquid interface has been initiated, the process might continue spontaneously in a zipper-like fashion, thus explaining that low amounts of hydrophobic surfactant protein are sufficient for optimal activity.

\section{Role of proteins in exogenous surfactants for clinical use}

The mission of an exogenous surfactant is to compensate for a defective endogenous supply (as in a preterm baby with RDS), or to overcome surfactant inhibition in clinical conditions characterized primarily by disturbance of lung permeability and accumulation of proteinaceous oedema in the airspaces (as in a patient with ARDS). Patients with pneumonia leading to surfactant dysfunction may also benefit from replacement therapy [286]. Optimal design of the exogenous surfactant preparation may vary with the clinical situation, including the degree of urgency for a therapeutic response. As mentioned above, a number of clinically relevant biophysical and physiological properties of an exogenous surfactant depend on the presence of specific proteins. These properties include speed of action, resistance to inactivation by leaking serum proteins, capacity to stimulate phagocytosis of bacteria and viruses by alveolar macrophages, and influence on bacterial proliferation. Some types of slow-acting exogenous surfactants seem mainly to upgrade the pool of alveolar phospholipids available for recycling, other preparations apparently provide material "ready for use", and therefore quickly restore stability and gas exchange in a surfactantdeficient lung. The proteins make the difference.

\section{Surfactant currently used in clinical practice}

The material administered to babies with RDS in the pioneering clinical trial of FuJIWARA et al. [7], Surfactant TA (Tokyo Tanabe, Tokyo, Japan), is based on natural lipids and hydrophobic proteins extracted from minced bovine lungs. Synthetic lipids are added to this surfactant to standardize composition and improve the physical and physiological properties. Surfactant TA is manufactured and marketed outside Japan, in slightly modified form, under the trade name Survanta (Abbott, North Chicago, IL, USA). Calf Lung Surfactant Extract (CLSE) [287], and its equivalent Infasurf (ONY, Buffalo, USA) [9], and Alveofact (Thomae, Biberach, Germany) [288] are other widely used bovine surfactants, isolated by lung washing and subsequent extraction of the lavage fluid with organic solvents. Curosurf (Chiesi Farmaceutici, Parma, Italy) [289], used in large European multicentre trials [11, 290, 291], is isolated from minced pig lungs, by a combination of washing, chloroform-methanol extraction and liquidgel chromatography. This surfactant differs from those previously listed by being devoid of triglycerides, cholesterol and cholesteryl esters. The content of hydrophobic proteins (SP-B, SP-C) is of the same order in all these preparations, about $1 \%$. The hydrophilic proteins (SP-A, SP-D) are absent [292].

Human surfactant, isolated from amniotic fluid by sucrose gradient centrifugation, as described by HALLMAN et al. [293], has been used mainly in Finland and California. It contains, apart from lipids, approximately $6 \%$ proteins, including hydrophilic (SP-A, SP-D, and nonsurfactant proteins), and hydrophobic polypeptides (SP-B, SP-C).

All these protein-containing preparations, which can be classified as "natural" or "modified natural" surfactants [294], are characterized by rapid adsorption to an air/liquid interface, and low minimum surface tension during cyclic film compression [292]. In a baby with RDS, tracheal instillation of an adequate dose of either type of surfactant usually results in a dramatic improvement of gas exchange. In the first controlled European multicentre trial of Curosurf for treatment of severe neonatal RDS [11], there was a threefold increase in the arterial-to-alveolar oxygen tension ratio $\left(\mathrm{a} / \mathrm{APO}_{2}\right)$ within 5 min of treatment with surfactant $\left(200 \mathrm{mg} \cdot \mathrm{kg}^{-1}\right)$. Such a rapid effect, requiring alertness of the attending neonatologist and nearly immediate adjustment of the ventilator setting, is not observed with protein-free synthetic surfactants ( $c f$ below).

Two synthetic surfactants are currently used in clinical practice. Artificial Lung Expanding Compound (ALEC) (Britannia Pharmaceuticals, Redhill, Surrey, UK) is a mixture of DPPC and unsaturated PG 7:3 (w/w), suspended in cold saline [295]. The name of the drug is an abbreviation, but also happens to be the first name of one of its inventors, Alec Bangham. The composition of the drug is based on the concept that unsaturated PG promotes spreading of DPPC at an air/liquid interface. This is undoubtedly true under controlled in vitro conditions, at least if the mixture is applied as dry particles onto the surface [296]. Spreading may be less effective after instillation of the material as an aqueous suspension into the airways. ALEC has been evaluated in preterm newborn 
animals, with conflicting results, some investigators reporting a moderate effect on lung compliance [297], others denying a physiological effect [298]. ALEC does not seem to be effective in babies with established RDS [299], but improves lung function, reduces mortality, and lowers the incidence of intraventricular haemorrhage when administered prophylactically, especially in babies with a gestational age of less than 30 weeks [295, 300]. Increased lung compliance has been reported in preterm babies treated with ALEC at birth, but this was not statistically significant until $6 \mathrm{~h}$ after administration of the drug [301]. The limited effects of ALEC in established RDS can probably be explained by the absence of proteins in the preparation.

Exosurf (Burroughs Wellcome, Research Triangle Park, NC, USA) is a mixture of DPPC, hexadecanol and tyloxapol 13.5:1.5:1 (by weight). The material is suspended in saline at a phospholipid concentration of $13.5 \mathrm{mg} \cdot \mathrm{ml}^{-1}$. The alcohol and the detergent are added to enhance spreading of the phospholipid at the air/liquid interfaces of the lung.

According to the original description of the product [302], a film of Exosurf has a minimum surface tension close to $0 \mathrm{mN} \cdot \mathrm{m}^{-1}$ during $40 \%$ surface compression in a pulsating-bubble system. This is in contrast to more recent observations [303], indicating that Exosurf adsorbs to an air/liquid interface much slower than natural surfactant, and that minimum surface tension remains at $29 \mathrm{mN} \cdot \mathrm{m}^{-1}$. Minimum surface tension of an organic solvent extract of natural surfactant in the same assay system is close to $0 \mathrm{mN} \cdot \mathrm{m}^{-1}[289,303]$.

Nevertheless, Exosurf improves gas exchange and lung compliance when instilled into the airways of preterm newborn experimental animals [302, 304], but this effect is less prominent than that obtained with natural surfactant. Exosurf also improves lung function in babies with RDS, but the therapeutic response is insidious [305], and may not be significant until after several hours. Some neonatologists regard this slow effect as an advantage, as it does not require quick readjustment of ventilator settings; others are less impressed and prefer fast-acting natural surfactant preparations.

Again, these biophysical and physiological differences reflect the absence of hydrophobic proteins in the synthetic product. In fact, recent studies with Exosurf have documented that its physical properties (film adsorption rate, minimum surface tension during cyclic film compression) can be improved significantly by adding hydrophobic proteins, in amounts similar to those present in modified natural surfactant isolated by extraction with organic solvents, i.e. $1 \%$ [303]. Corresponding data were obtained in quasi-static pressure-volume recordings on surfactant-depleted excised rat lungs. Exosurf alone failed to restore normal stability during deflation, but with hydrophobic proteins added the effects of the synthetic preparation approached that of natural surfactant extract (CLSE) [303].

\section{Surfactant proteins and resistance to inhibition}

In addition to their direct effects on film adsorption and stability, the surfactant-associated proteins seem to influence resistance to inhibition. Surfactant preparations with admirable in vitro properties, including minimum surface tension close to $0 \mathrm{mN} \cdot \mathrm{m}^{-1}$ during cyclic film compression, can be made from a mixture of DPPC and PA $(9: 1, w / w)$. However, such an artificial surfactant is easily inactivated by serum proteins, and fails to restore normal deflation stability in surfactant-depleted adult lungs [268]. When hydrophobic proteins are added to a suspension of DPPC and egg-PG, the product becomes more resistant to inhibition by albumin [306]. This is also the case for surfactant containing DPPC/PG/PA 68.5:22.5:9 (by weight) and 2\% recombinant SP-C, compared to a protein-free suspension of the same lipids [267]. Addition of SP-A to a natural surfactant extract (containing lipids, SP-B and SP-C) also seems to increase resistance to inhibition by albumin and fibrinogen [266]. These differences between various exogenous surfactant preparations may be important in the treatment of ARDS, a disease characterized by a disturbance of lung permeability rather than primary deficiency of surfactant.

\section{Surfactant proteins and lung defence}

As mentioned above, SP-A stimulates phagocytosis of bacteria and viruses by alveolar macrophages [38-40, 307], and both SP-A and SP-D enhance the production of oxygen radicals by the same cells [205]. The presence of these proteins in an exogenous surfactant preparation may, therefore, influence the clinical response to replacement therapy in a baby with pneumonia. Studies on preterm newborn rabbits infected with aerosolized Group B streptococci (GBS) have indicated that the magnitude of bacterial proliferation in the lungs varies with the type of surfactant instilled into the airways. Exosurf had a bacteriostatic effect; with natural surfactant extract and human amniotic fluid, bacterial proliferation occurred but was not increased compared to inoculated control animals not receiving surfactant [308]. In our studies, treatment with Curosurf reduced $5 \mathrm{~h}$ proliferation of GBS inoculated into the lungs of near-term newborn rabbits, in comparison with nontreated infected controls (Herting et al., unpublished). More systematic studies, confronting pneumonia caused by different micro-organisms with different types of surfactants (with or without different surfactant-associated proteins), are clearly required to evaluate the potential of surfactant treatment in infectious lung disease, and to further clarify the roles of surfactant proteins in the pulmonary defence system.

\section{Perspectives for the future}

In the near future, a new generation of artificial surfactants will probably be introduced in clinical practice. These are likely to contain surfactant proteins or analogous polypeptides that are either synthesized or produced by gene expression in bacterial or other cell culture systems, and then "reconstituted" with DPPC and, perhaps, other synthetic lipids. Artificial surfactants based on SP-B, SP-C or peptide analogues have been developed, but the 
physiological properties of these various preparations have, so far, remained inferior to those of natural surfactant $[66,74,133,207,209,215,216,218,238,248,249$, 256-263, 267, 268, 309]. Certain fundamental problems in this context remain to be resolved. These relate to the three-dimensional orientation of the hydrophobic proteins in the aggregates of surfactant lipids generating the surface film. Proper understanding of the interaction between lipids and proteins in the surfactant system is a prerequisite for a rational approach to making artificial surfactant substitutes for replacement therapy.

Acknowledgements: JJ is grateful to H. Jörnvall for continuous support.

\section{References}

1. von Neergaard K. Neue Auffassungen über einen Grundbegriff der Atemmechanik. Z Gesamte Exp Med 1929; 66: 373-394.

2. Pattle RE. Properties, function and origin of the alveolar lining layer. Nature 1955; 175: 1125-1126.

3. Clements JA. Surface tension of lung extracts. Proc Soc Exp Biol Med 1957; 95: 170-172.

4. Avery ME, Mead J. Surface properties in relation to atelectasis and hyaline membrane disease. Am J Dis Child 1959; 97: 517-523.

5. Farrell PM, Avery ME. Hyaline membrane disease. Am Rev Respir Dis 1975; 111: 657-688.

6. Hochheim K. Üeber einige Befunde in den Lungen von Neugeborenen und die Beziehung derselben zur Aspiration von Fruchtwasser. Centralblatt Pathol 1903; 14: 537538.

7. Fujiwara T, Maeta H, Chida S, Morita T, Watabe Y, Abe T. Artificial surfactant therapy in hyaline membrane disease. Lancet 1980; i: 55-59.

8. Shapiro DL, Notter RH, eds. Surfactant Replacement Therapy. New York, Alan R. Liss, 1989.

9. Enhorning, G, Shennan A, Possmayer, F, Dunn M, Chen CP, Milligan J. Prevention of neonatal respiratory distress syndrome by tracheal instillation of surfactant: a randomized clinical trial. Pediatrics 1985; 76: 145-153.

10. Hallman M, Merritt TA, Jarvenpaa AL, et al. Exogenous human surfactant for treatment of severe respiratory distress syndrome: a randomized prospective clinical trial. J Pediatr 1985; 106: 963-969.

11. Collaborative European Multicenter Study Group. Surfactant replacement therapy for severe neonatal respiratory distress syndrome: an international randomized clinical trial. Pediatrics 1988; 82: 683-691.

12. Metcalfe IL, Enhorning G, Possmayer F. Pulmonary surfactant-associated proteins: their role in the expression of surface activity. J Appl Physiol 1980; 49: 34-41.

13. Morley C, Bangham A. Physical properties of surfactant under compression. Prog Respir Res 1981; 15: 188193.

14. Schürch S, Goerke J, Clements JA. Direct determination of surface tension in the lung. Proc Natl Acad Sci USA 1976; 73: 4698-4702.

15. Askin FB, Kuhn C. The cellular origin of pulmonary surfactant. Lab Invest 1971; 25: 260-268.

16. Chevalier G, Collet AJ. In vivo incorporation of choline${ }^{3} \mathrm{H}$, leucine $-{ }^{3} \mathrm{H}$ and galactose- ${ }^{3} \mathrm{H}$ in alveolar type II pneumocytes in relation to surfactant synthesis. A quantitative radioautographic study in mouse by electron microscopy. Anat Rec 1972; 174: 289-310.
17. Macklin CC. The pulmonary alveolar mucoid film and the pneumocytes. Lancet 1954; i: 1099-1104.

18. Ryan US, Ryan JW, Smith DS. Alveolar type II cells: studies on the mode of release of lamellar bodies. Tissue Cell 1975; 3: 587-599.

19. Williams MC. Conversion of lamellar body membranes into tubular myelin in alveoli of fetal rat lungs. J Cell Biol 1977; 72: 260-277.

20. Williams MC. Ultrastructure of tubular myelin and lamellar bodies in fast-frozen adult rat lung. Exp Lung Res 1982; 4: 37-46.

21. Weibel ER, Kistler GS, Töndury G. A stereological electron microscope study of "tubular myelin figures" in alveolar fluids of rat lungs. Z Zellforsch 1966; 69: 418-427.

22. Gil J, Weibel ER. Improvements in demonstration of lining layer of lung alveoli by electron microscopy. Respir Physiol 1969; 8: 13-36.

23. Goerke J. Lung surfactant. Biochim Biophys Acta 1974; 344: 241-261.

24. Manabe T. Freeze-fracture study of alveolar lining layer in adult rat lungs. J Ultrastruct Res 1979; 69: 86-97.

25. King RJ, Clements JA. Surface active material from dog lung. II. Composition and physiological correlations. Am J Physiol 1972; 223: 715-726.

26. King RJ, Macbeth MC. Physicochemical properties of dipalmitoylphosphatidylcholine after interaction with an apolipoprotein of pulmonary surfactant. Biochim Biophys Acta 1979; 557: 86-101.

27. Geiger K, Gallagher ML, Hedley-Whyte J. Cellular distribution and clearance of aerosolized dipalmitoyl lecithin. J Appl Physiol 1975; 39: 759-766.

28. Nichols BA. Normal rabbit alveolar macrophages I. The phagocytosis of tubular myelin. J Exp Med 1976; 144: 906-919.

29. Williams MC, Benson BJ. Immunocytochemical localization and identification of the major surfactant protein in adult rat lung. J Histochem Cytochem 1981; 29: 291-305.

30. Jarstrand C, Berggren P, Curstedt T, Johansson A, Robertson B, Wiernik A. Influence of lung surfactant phospholipids on neutrophilic granulocytes and blood monocytes. Prog Respir Res 1984; 18: 44-50.

31. O'Neill SJ, Lesperance E, Klass DJ. Human lung lavage surfactant enhances staphylococcal phagocytosis by alveolar macrophages. Am Rev Respir Dis 1984; 130: 11771179 .

32. Tenner AJ, Robinson SL, Borchelt J, Wright JR. Human pulmonary surfactant protein (SP-A), a protein structurally homologous to C1q, can enhance FcR- and CR1-mediated phagocytosis. J Biol Chem 1989; 264: 13923-13928.

33. LaForce FM, Kelly WJ, Huber GL. Inactivation of staphylococci by alveolar macrophages with preliminary observations on the importance of alveolar lining material. Am Rev Respir Dis 1973; 108: 784-790.

34. LaForce FM. Effect of alveolar lining material on phagocytic and bacteriocidal activity of lung macrophages against Staphylococcus aureus. J Lab Clin Med 1976; 88: 691-699.

35. Hoffman RM, Claypool WD, Katyal SL, Singh G, Rogers RM, Dauber JH. Augmentation of rat alveolar macrophage migration by surfactant protein. Am Rev Respir Dis 1987; 135: $1358-1362$.

36. Jonsson S, Musher DM, Goree A, Lawrence EC. Human alveolar lining material and antibacterial defenses. $\mathrm{Am}$ Rev Respir Dis 1986; 133: 136-140. 
37. Zimmerman PE, Voelker DR, McCormack FX, Paulsrud JR, Martin II WJ. $120 \mathrm{kD}$ surface glycoprotein of Pneumocystis carinii is a ligand for surfactant protein A. $J$ Clin Invest 1992; 89: 143-149.

38. van Iwaarden JF, van Strijp JAG, Visser H, Haagsman HP, Verhoef J, van Golde LMG. Binding of surfactant protein A (SP-A) to herpes simplex virus type 1-infected cells is mediated by the carbohydrate moiety of SP-A. J Biol Chem 1992; 267: 25039-25043.

39. van Iwaarden F, Welmers B, Verhoef J, Haagsman HP, van Golde LMG. Pulmonary surfactant protein A enhances the host-defense mechanism of rat alveolar macrophages. Am J Respir Cell Mol Biol 1990; 2: 91-98.

40. Manz-Keinke H, Plattner H, Schlepper-Schäfer J. Lung surfactant protein A (SP-A) enhances serum-independent phagocytosis of bacteria by alveolar macrophages. Eur J Cell Biol 1992; 57: 95-100.

41. Golde DW, Territo M, Finley TN, Cline MJ. Defective lung macrophages in pulmonary alveolar proteinosis. Ann Intern Med 1976; 85: 304-309.

42. Harris JO. Pulmonary alveolar proteinosis. Abnormal in vitro function of alveolar macrophages. Chest 1979; 76: 156-159.

43. Ansfield MJ, Kaltreider HB, Benson BJ, Caldwell JL. Immunosuppressive activity of canine pulmonary surface active material. J Immunol 1979; 122: 1062-1066.

44. Catanzaro A, Richman P, Batcher S, Hallman M. Immunomodulation by pulmonary surfactant. J Lab Clin Med 1988; 112: 727-734.

45. Ansfield MJ, Benson BJ. Identification of the immunosuppressive components of canine pulmonary surface active material. J Immunol 1980; 125: 1093-1098.

46. King RJ, Clements JA. Surface active material from dog lung. I. Method of isolation. Am J Physiol 1972; 223: 707-714.

47. King RJ, Klass DJ, Gikas EG, Clements JA. Isolation of apoproteins from canine surface active material. Am J Physiol 1973; 224: 788-795.

48. Shelley SA, Paciga JE, Balis JU. Lung surfactant phospholipids in different animal species. Lipids 1984; 19: 857-862.

49. Post M, Batenburg JJ, Schuurmans EAJM, Laros CD, van Golde LMG. Lamellar bodies isolated from adult human lung tissue. Exp Lung Res 1982; 3: 17-28.

50. Alberts B, Bray D, Lewis J, Raff M, Roberts K, Watson JD. Molecular Biology of the Cell. New York, Garland Publishing, 1989; p. 281.

51. Klaus MH, Clements JA, Havel R. Composition of surface-active material isolated from beef lung. Proc Natl Acad Sci USA 1961; 47: 1858-1859.

52. Curstedt T. Biosynthesis of molecular species of phosphatidylcholines in bile, liver and plasma of rats given $\left[1,1-{ }^{2} \mathrm{H}_{2}\right]$ ethanol. Biochim Biophys Acta 1974; 369: 196-208.

53. Wright JR, Clements JA. Metabolism and turnover of lung surfactant. Am Rev Respir Dis 1987; 135: 426-444.

54. Clements JA, Nellenbogen J, Trahan HJ. Pulmonary surfactant and evolution of the lungs. Science 1970; 169: 603-604.

55. Gail DB, Steinkamp H, Massaro D. Interspecies variation in lung lavage and tissue saturated phosphatidyl-choline. Respir Physiol 1978; 33: 289-297.

56. Phizackerley PJR, Town MH, Newman GE. Hydrophobic proteins of lamellated osmiophilic bodies isolated from pig lung. Biochem J 1979; 183: 731-736.

57. Floros J, Steinbrink R, Jacobs K, et al. Isolation and characterization of cDNA clones for the $35 \mathrm{kDa}$ pulmonary surfactant-associated protein. J Biol Chem 1986; 261: 9029-9033.

58. White RT, Damm D, Miller J, et al. Isolation and characterization of the human pulmonary surfactant apoprotein gene. Nature 1985; 317: 361-363.

59. Benson B, Hawgood S, Schilling J, et al. Structure of canine pulmonary surfactant apoprotein: cDNA and complete amino acid sequence. Proc Natl Acad Sci USA 1985; 82: 6379-6383.

60. Sano K, Fisher J, Mason RJ, et al. Isolation and sequence of a cDNA clone for the rat pulmonary surfactant-associated protein (PSP-A). Biochem Biophys Res Commun 1987; 144: 367-374.

61. Voss T, Eistetter H, Schäfer KP. Macromolecular organization of natural and recombinant lung surfactant protein SP 28-36. J Mol Biol 1988; 201: 219-227.

62. Curstedt T, Johansson J, Barros-Söderling J, et al. Lowmolecular-mass surfactant protein type 1 . The primary structure of a hydrophobic $8 \mathrm{kDa}$ polypeptide with eight half-cystine residues. Eur J Biochem 1988; 172: 521525.

63. Johansson J, Curstedt T, Jörnvall H. Surfactant protein B: disulfide bridges, structural properties, and kringle similarities. Biochemistry 1991; 30: 6917-6921.

64. Johansson J, Jörnvall H, Curstedt T. Human surfactant polypeptide SP-B: disulfide bridges, C-terminal end, and peptide analysis of the airway form. FEBS Lett 1992; 301: 165-167.

65. Curstedt T, Johansson J, Persson P, et al. Hydrophobic surfactant-associated polypeptides: SP-C is a lipopeptide with two palmitoylated cysteine residues, whereas SP-B lacks covalently linked fatty acyl groups. Proc Natl Acad Sci USA 1990; 87: 2985-2989.

66. Johansson J, Curstedt T, Robertson B, Jörnvall H. Size and structure of the hydrophobic low molecular weight surfactant-associated polypeptide. Biochemistry 1988; 27: 3544-3547.

67. Johansson J, Jörnvall H, Eklund A, Christensen N, Robertson B, Curstedt T. Hydrophobic 3.7 kDa surfactant polypeptide: structural characterization of the human and bovine forms. FEBS Lett 1988; 232: 61-64.

68. Johansson J, Persson P, Löwenadler B, Robertson B, Jörnvall $\mathrm{H}$, Curstedt $\mathrm{T}$. Canine hydrophobic surfactant poly-peptide SP-C: a lipopeptide with one thioester-linked palmitoyl group. FEBS Lett 1991; 281: 119-122.

69. Persson A, Rust K, Chang D, Moxley M, Longmore W, Crouch E. CP4: a pneumocyte-derived collagenous surfactant-associated protein. Evidence for heterogeneity of collagenous surfactant proteins. Biochemistry 1988; 27: 8576-8584.

70. Lu J, Willis AC, Reid KBM. Purification, characterization and cDNA cloning of human lung surfactant protein D. Biochem J 1992; 284: 795-802.

71. Shimizu H, Fisher JH, Papst P, et al. Primary structure of rat pulmonary surfactant protein D: cDNA and deduced amino acid sequence. J Biol Chem 1992; 267: 1853-1857.

72. Ng VL, Herndon VL, Mendelson CR, Snyder JM. Characterization of rabbit surfactant-associated proteins. Biochim Biophys Acta 1983; 754: 218-226.

73. Possmayer F. A proposed nomenclature for pulmonary surfactant-associated proteins. Am Rev Respir Dis 1988; 138: 990-998.

74. Curstedt T, Jörnvall H, Robertson B, Bergman T, Berggren P. Two hydrophobic low-molecular-mass protein fractions of pulmonary surfactant. Characterization and biophysical activity. Eur J Biochem 1987; 168: 255-262.

75. Johansson J, Gröndal S, Sjövall J, Jörnvall H, Curstedt 
T. Identification of hydrophobic fragments of $\alpha_{1}$-antitrypsin and $\mathrm{C} 1$ protease inhibitor in human bile, plasma and spleen. FEBS Lett 1992; 299: 146-148.

76. Korfhagen TR, Glasser SW, Wert SE, et al. Cis-acting sequences from a human surfactant protein gene confer pulmonary-specific gene expression in transgenic mice. Proc Natl Acad Sci USA 1990; 87: 6122-6126.

77. Glasser SW, Korfhagen TR, Bruno MD, Dey C, Whitsett JA. Structure and expression of the pulmonary surfactant protein SP-C gene in the mouse. J Biol Chem 1990; 265: 21986-21991.

78. Eliakim R, Deschryver-Kecskemeti K, Nogee L, Stenson WF, Alpers DH. Isolation and characterization of a small intestinal surfactant-like particle containing alkaline phosphatase and other digestive enzymes. J Biol Chem 1989; 264: 20614-20619.

79. Yamanaka N, Kobayashi K, Kataura A, Kuroki Y, Akino T. Implication of surfactant apoprotein in otitis media with effusion. Ann Otol Rhinol Laryngol 1991; 100: 835-840.

80. Crapo JD, Young SL, Fram EK, Pinkerton KE, Barry BE, Crapo RO. Morphometric characteristics of cells in the alveolar region of mammalian lungs. Am Rev Respir Dis 1983; 128: S42-S46.

81. van Golde LMG, Batenburg JJ, Robertson B. The pulmonary surfactant system: biochemical aspects and functional significance. Physiol Rev 1988; 68: 374-455.

82. Batenburg JJ, den Breejen JN, Yost RW, Haagsman HP, van Golde LMG. Glycerol 3-phosphate acylation in microsomes of type II cells isolated from adult rat lung. Biochim Biophys Acta 1986; 878: 301-309.

83. Sueishi K, Tanaka K, Oda T. Immuno-ultrastructural study of surfactant system. Distribution of specific protein of surface active material in rabbit lung. Lab Invest 1977; 37: 136-142.

84. Balis JU, Paterson JF, Paciga JE, Haller EM, Shelley SA. Distribution and subcellular localization of surfactantassociated glycoproteins in human lung. Lab Invest 1985 ; 52: 657-669.

85. Walker SR, Williams MC, Benson B. Immunocytochemical localization of the major surfactant apoproteins in type II cells, Clara cells and alveolar macrophages of rat lung. J Histochem Cytochem 1986; 34: 1137-1148.

86. Suzuki Y, Kogishi K, Fujita Y. Ultrastructural localization and its possible role on the surface activity of the 15,000 dalton protein associated with pig pulmonary surfactant. J Jpn Med Soc Biol Interface 1986; 17: 76-82.

87. Katyal SL, Singh G, Ryan L, Gottron S. Hydrophobic surfactant-associated proteins: electrophoretic and immunologic analyses and cellular localization in human lung. Exp Lung Res 1988; 14: 655-669.

88. Coalson JJ, Winter VT, Martin HM, King RJ. Colloidal gold immuno-ultrastructural localization of rat surfactant. Am Rev Respir Dis 1986; 133: 230-237.

89. Suzuki Y, Kogishi K, Fujita Y, Kina T, Nishikawa S. A monoclonal antibody to the 15,000 dalton protein associated with porcine pulmonary surfactant. Exp Lung Res 1986; 11: 61-73.

90. Oosterlaken-Dijksterhuis MA, van Eijk M, van Buel BLM, van Golde LMG, Haagsman HP. Surfactant protein composition of lamellar bodies isolated from rat lung. Biochem J 1991; 274: 115-119.

91. Voorhout WF, Veenendaal T, Kuroki Y, Ogasawara Y, van Golde LMG, Geuze HJ. Immunocytochemical localization of surfactant protein D (SP-D) in type II cells, Clara cells, and alveolar macrophages of rat lung. J Histochem Cytochem 1992; 40: 1589-1597.
92. Froh D, Gonzales LW, Ballard PL. Secretion of surfactant protein A and phosphatidylcholine from type II cells of human fetal lung. Am J Respir Cell Mol Biol 1993; 8: 556-561.

93. Phelps DS, Floros J. Localization of surfactant protein synthesis in human lung by in situ hybridization. Am Rev Respir Dis 1988; 137: 939-942.

94. Mettler NR, Gray ME, Schuffman S, Lequire VS. $\beta-$ adrenergic induced synthesis and secretion of phosphatidylcholine by isolated pulmonary alveolar type II cells. $L a b$ Invest 1981; 45: 575-586.

95. Oyarzun MJ, Clements JA. Ventilatory and cholinergic control of pulmonary surfactant in the rabbit. J Appl Physiol 1977; 43: 39-45.

96. Oyarzun MJ, Clements JA. Control of lung surfactant by ventilation, adrenergic mediators and prostaglandins in the rabbit. Am Rev Respir Dis 1978; 117: 879-891.

97. Dobbs LG, Mason RJ. Pulmonary alveolar type II cells isolated from rats. Release of phosphatidylcholine in response to $\beta$-adrenergic stimulation. J Clin Invest 1979; 63: $378-387$.

98. Sano K, Voelker DR, Mason RJ. Involvement of protein kinase $\mathrm{C}$ in pulmonary surfactant secretion from alveolar type II cells. J Biol Chem 1985; 260: 12725-12729.

99. Gilfillan AM, Rooney SA. Leukotrienes stimulate phosphatidylcholine secretion in cultured type II pneumocytes. Biochim Biophys Acta 1986; 876: 22-27.

100. Rooney SA, Gobran LI. Adenosine and leukotrienes have a regulatory role in lung surfactant secretion in the newborn rabbit. Biochim Biophys Acta 1988; 960: 98106.

101. Dobbs LG, Gonzalez RF, Marinari LA, Mescher EJ, Hawgood S. The role of calcium in the secretion of surfactant by rat alveolar type II cells. Biochim Biophys Acta 1986; 877: 305-313.

102. Rice WR, Ross GF, Singleton FM, Dingle S, Whitsett JA. Surfactant-associated protein inhibits phospholipid secretion from type II cells. J Appl Physiol 1987; 63: 692-698.

103. Dobbs LG, Wright JR, Hawgood S, Gonzalez R, Venstrom K, Nellenbogen J. Pulmonary surfactant and its components inhibit secretion of phosphatidylcholine from cultured rat alveolar type II cells. Proc Natl Acad Sci USA 1987; 84: 1010-1014.

104. Wright JR, Borchelt JD, Hawgood S. Lung surfactant apoprotein SP-A (26-36 kDa) binds with high affinity to isolated alveolar type II cells. Proc Natl Acad Sci USA 1989; 86: 5410-5414.

105. Kuroki Y, Mason RJ, Voelker DR. Pulmonary surfactant apoprotein A structure and modulation of surfactant secretion by rat alveolar type II cells. J Biol Chem 1988; 263: 3388-3394.

106. Kuroki Y, Mason RJ, Voelker DR. Chemical modification of surfactant protein A alters high affinity binding to rat alveolar type II cells and regulation of phospholipid secretion. J Biol Chem 1988; 263: 17596-17602.

107. Rice WR, Singleton FM. Regulation of surfactant phopholipid secretion from isolated rat alveolar type II cells by lectins. Biochim Biophys Acta 1988; 958: 205210.

108. Postle AD, Hunt AN, Normand CS. The proteins of human lung surfactant. Biochim Biophys Acta 1985; 837: 305-313.

109. Tsilibary EC, Williams MC. Actin and secretion of surfactant. J Histochem Cytochem 1983; 31: 1298-1304.

110. Whitsett JA, Hull WM, Dion C, Lessard J. cAMPdependent actin phosphorylation in developing rat lung 
and type II epithelial cells. Exp Lung Res 1985; 9: 191-209.

111. Schellhase DE, Emrie PA, Fisher JH, Shannon JM. Ontogeny of surfactant apoproteins in the rat. Pediatr Res 1989; 26: 167-174.

112. Ballard PL. Hormonal regulation of pulmonary surfactant. Endocrin Rev 1989; 10: 165-181.

113. Weaver TE, Whitsett JA. Function and regulation of expression of pulmonary surfactant-associated proteins. Biochem J 1991; 273: 249-264.

114. Liley HG, White RT, Warr RG, Benson BJ, Hawgood $\mathrm{S}$, Ballard PL. Regulation of messenger RNAs for the hydrophobic surfactant proteins in human lung. J Clin Invest 1989; 83: 1191-1197.

115. Ballard PL, Hawgood S, Liley H, et al. Regulation of pulmonary surfactant apoprotein SP 28-36 gene in fetal human lung. Proc Natl Acad Sci USA 1986; 83: 95279531.

116. McMahan MJ, Mimouni F, Miodovnik M, Hull WM, Whitsett JA. Surfactant associated protein (SAP-35) in amniotic fluid from diabetic and nondiabetic pregnancies. Obstet Gynecol 1987; 70: 94-98.

117. Slavkin HC, Johnson R, Oliver P, et al. Lamellar body formation precedes pulmonary surfactant apoprotein expression during embryonic mouse lung development in vivo and in vitro. Differentiation 1989; 41: 223-236.

118. O'Reilly MA, Nogee L, Whitsett JA. Requirement of the collagenous domain for carbohydrate processing and secretion of a surfactant protein, SP-A. Biochim Biophys Acta 1988; 969: 176-184.

119. Whitsett JA, Weaver TE, Clark JC, et al. Glucocorticoids enhance surfactant proteolipid Phe and pVal synthesis and RNA in fetal lung. J Biol Chem 1987; 262: 15618-15623.

120. Venkatesh VC, Iannuzzi DM, Ertsey R, Ballard PL. Differential glucocorticoid regulation of the pulmonary hydro-phobic surfactant proteins SP-B and SP-C. Am J Respir Cell Mol Biol 1993; 8: 222-228.

121. Whitsett JA, Pilot-Matias T, Clark JC, Weaver TE. Induction of surfactant protein in fetal lung. Effects of cAMP and dexamethasone on SAP-35 RNA and synthesis. J Biol Chem 1987; 262: 5256-5261.

122. O'Reilly MA, Gazdar AF, Clark JC, et al. Glucocorticoids regulate surfactant protein synthesis in a pulmonary adenocarcinoma cell line. Am J Physiol 1989; 257: L385-L392.

123. Liley HG, White RT, Benson BJ, Ballard PL. Glucocorticoids both stimulate and inhibit production of pulmonary surfactant protein A in fetal human lung. Proc Natl Acad Sci USA 1988; 85: 9096-9100.

124. Odom MJ, Snyder JM, Boggaram V, Mendelson CR. Glucocorticoid regulation of the major surfactant associated protein (SP-A) and its messenger ribonucleic acid and of morphological development of human fetal lung in vitro. Endocrinology 1988; 123: 1712-1720.

125. Boggaram V, Smith ME, Mendelson CR. Regulation of expression of the gene encoding the major surfactant protein (SP-A) in human fetal lung in vitro. Disparate effects of glucocorticoids on transcription and on mRNA stability. J Biol Chem 1989; 264: 11421-11427.

126. O'Reilly MA, Gazdar AF, Morris RE, Whitsett JA. Differential effects of glucocorticoid on expression of surfactant proteins in a human lung adenocarcinoma cell line. Biochim Biophys Acta 1988; 970: 194-204.

127. Boggaram V, Mendelson CR. Transcriptional regulation of the gene encoding the major surfactant protein (SPA) in rabbit fetal lung. J Biol Chem 1988; 263: 19060-19065.

128. Mendelson CR, Chen C, Boggaram V, Zacharias C,
Snyder JM. Regulation of the synthesis of the major surfactant apoprotein in fetal rabbit lung tissue. J Biol Chem 1986; 261: 9938-9943.

129. Whitsett JA, Weaver TE, Lieberman MA, Clark JC, Daugherty C. Differential effects of epidermal growth factor and transforming growth factor- $\beta$ on synthesis of $\mathrm{M}_{\mathrm{r}}=35,000$ surfactant-associated protein in fetal lung. $J$ Biol Chem 1987; 262: 7908-7913.

130. Enhörning G. In search of an artificial pulmonary surfactant. J Jap Med Soc Biol Interface 1984; 15: 73-81.

131. Clements JA. Functions of the alveolar lining. Am Rev Respir Dis 1977; 115: 67-71.

132. Bangham AD, Morley CJ, Phillips MC. The physical properties of an effective lung surfactant. Biochim Biophys Acta 1979; 573: 552-556.

133. Yu SH, Possmayer F. Role of bovine pulmonary surfactant-associated proteins in the surface-active property of phospholipid mixtures. Biochim Biophys Acta 1990; 1046: 233-241.

134. Mathialagan N, Possmayer F. Low-molecular-weight hydrophobic proteins from bovine pulmonary surfactant. Biochim Biophys Acta 1990; 1045: 121-127.

135. Baritussio AG, Magoon MW, Goerke J, Clements JA. Precursor-product relationship between rabbit type II cell lamellar bodies and alveolar surface-active material. Biochim Biophys Acta 1981; 666: 382-393.

136. Hallman M, Epstein BL, Gluck L. Analysis of labeling and clearance of lung surfactant phospholipids in rabbit. Evidence of bidirectional surfactant flux between lamellar bodies and alveolar lavage. J Clin Invest 1981; 68: 742-751.

137. Baritussio A, Benevento M, Pettenazzo A, et al. The life cycle of a low-molecular-weight protein of surfactant (SP-C) in 3 day old rabbits. Biochim Biophys Acta 1989; 1006: 19-25.

138. Baritussio A, Pettenazzo A, Benevento M, Alberti A, Gamba P. Surfactant protein $C$ is recycled from the alveoli to the lamellar bodies. Am J Physiol 1992; 263 : L607-L611.

139. Young SL, Kremers SA, Apple JS, Crapo JD, Brumley GW. Rat lung surfactant kinetics: biochemical and morphometric correlation. J Appl Physiol 1981; 51: 248-253.

140. Jacobs H, Jobe A, Ikegami M, Jones S, Miller D. Route of incorporation of alveolar palmitate and choline into surfactant phosphatidylcholine in rabbits. Biochim Biophys Acta 1983; 752: 178-181.

141. Jacobs H, Jobe A, Ikegami M, Conaway D. The significance of reutilization of surfactant phosphatidylcholine. J Biol Chem 1983; 258: 4156-4165.

142. Jacobs HC, Ikegami M, Jobe AH, Berry DD, Jones S. Reutilization of surfactant phosphatidylcholine in adult rabbits. Biochim Biophys Acta 1985; 837: 77-84.

143. Jacobs HC, Jobe AH, Ikegami M, Jones S. Reutilization of phosphatidylglycerol and phosphatidylethanolamine by the pulmonary surfactant system in 3 day old rabbits. Biochim Biophys Acta 1985; 834: 172-179.

144. Meban C. Lung surfactant anchor. Nature 1987; 326: 252.

145. Williams MC, Sueishi K, Benson BJ. Localization of a surfactant apoprotein in multivesicular bodies of type II cells. Prog Respir Res 1984; 18: 101-105.

146. Wright JR, Wager RE, Hamilton RL, Huang M, Clements JA. Uptake of lung surfactant subfractions into lamellar bodies of adult rabbit lungs. J Appl Physiol 1986; 60: 817-825.

147. Wright JR, Wager RE, Hawgood S, Dobbs L, Clements 
JA. Surfactant apoprotein $M_{r}=26,000-36,000$ enhances uptake of liposomes by type II cells. J Biol Chem 1987; 262: 2888-2894.

148. Griese M, Gobran LI, Rooney SA. Surfactant lipid uptake and secretion in type II cells in response to lectins and secretagogues. Am J Physiol 1991; 261: L434442.

149. Ryan RM, Morris RE, Rice WR, Ciraolo G, Whitsett JA. Binding and uptake of pulmonary surfactant protein (SPA) by pulmonary type II epithelial cells. J Histochem Cytochem 1989; 37: 429-440.

150. Claypool WD, Wang DL, Chander A, Fisher AB. An ethanol/ether soluble apoprotein from rat lung surfactant augments liposome uptake by isolated granular pneumocytes. $J$ Clin Invest 1984; 74: 677-684.

151. Thakur NR, Tesan M, Tyler NE, Bleasdale JE. Altered lipid synthesis in type II pneumocytes exposed to lung surfactant. Biochem J 1986; 240: 679-690.

152. Bates SR, Ibach PB, Fisher AB. Phospholipids coisolated with rat surfactant protein $C$ account for the apparent protein-enhanced uptake of liposomes into lung granular pneumocytes. Exp Lung Res 1989; 15: 695-708.

153. Rice WR, Sarin VK, Fox JL, Baatz J, Wert S, Whitsett JA. Surfactant peptides stimulate uptake of phosphatidylcholine by isolated cells. Biochim Biophys Acta 1989; 1006: 237-245.

154. Sueishi K, Benson BJ. Isolation of a major apolipoprotein of canine and murine pulmonary surfactant. Biochemical and immunochemical characteristics. Biochim Biophys Acta 1981; 665: 442-453.

155. Hawgood S, Benson BJ, Hamilton RL Jr. Effects of a surfactant-associated protein and calcium ions on the structure and surface activity of lung surfactant lipids. Biochemistry 1985; 24: 184-190.

156. Katyal SL, Singh G. An immunologic study of the apoproteins of rat lung surfactant. Lab Invest 1979; 40: 562-567.

157. Katyal SL, Singh G. Analysis of pulmonary surfactant apoproteins by electrophoresis. Biochim Biophys Acta 1981; 670: 323-331.

158. Phelps DS, Taeusch HW Jr, Benson B, Hawgood S. An electrophoretic and immunochemical characterization of human surfactant-associated proteins. Biochim Biophys Acta 1984; 791: 226-238.

159. Weaver TE, Whitsett JA, Hull WM, Ross G. Identification of canine pulmonary surfactant-associated glycoprotein A precursors. J Appl Physiol 1985; 58: 2091-2095.

160. Floros J, Phelps DS, Taeusch HW. Biosynthesis and $i$ $n$ vitro translation of the major surfactant-associated protein from human lung. J Biol Chem 1985; 260: 495-500.

161. Shelley SA, Paciga JE, Lowell NE, Balis JU. Immunologically related multimeric forms of 30-40 kDa peptides associated with lung surfactant in various mammalian species. Biochim Biophys Acta 1985; 839: 50-56.

162. Whitsett JA, Hull W, Ross G, Weaver T. Characteristics of human surfactant-associated glycoproteins A. Pediatr Res 1985; 19: 501-508.

163. Whitsett JA, Ross G, Weaver T, Rice W, Dion C, Hull W. Glycolsylation and secretion of surfactant-associated glycoprotein A. J Biol Chem 1985; 260: 15273-15279.

164. Katyal SL, Singh G. Analysis of pulmonary surfactant apoproteins by isoelectric focusing. Biochim Biophys Acta 1984; 794: 411-418.

165. Whitsett JA, Weaver T, Hull W, Ross G, Dion C. Synthesis of surfactant-associated glycoprotein A by rat type II epithelial cells. Primary translation products and posttranslational modification. Biochim Biophys Acta 1985; 828: 162-171.

166. Weaver TE, Hull WM, Ross G, Whitsett JA. In vitro acetylation of rat pulmonary surfactant-associated glycoprotein(s) A primary translation products. Biochim Biophys Acta 1986; 869: 330-336.

167. Weaver TE, Kropp KL, Whitsett JA. In vitro sulfation of pulmonary surfactant-associated protein-35. Biochim Biophys Acta 1987; 914: 205-211.

168. Phelps DS, Floros J. Proline hydroxylation alters the electrophoretic mobility of pulmonary surfactant-associated protein A. Electrophoresis 1988; 9: 231-233.

169. Rannels SR, Gallaher KJ, Wallin R, Rannels DE. Vitamin K-dependent carboxylation of pulmonary surfactantassociated proteins. Proc Natl Acad Sci USA 1987; 84: 5952-5956.

170. Wallin R, Seaton M, Martin LF. No evidence for vitamin K-dependent carboxylation of canine surfactant apoproteins, 28-36 kDa. Biochem J 1988; 252: 851-856.

171. Haagsman HP, Sargeant T, Hauschka PV, Benson BJ, Hawgood S. Binding of calcium to SP-A, a surfactantassociated protein. Biochemistry 1990; 29: 88948900.

172. Boggaram V, Qing K, Mendelson CR. The major apoprotein of rabbit pulmonary surfactant. Elucidation of primary sequence and cyclic AMP and developmental regulation. J Biol Chem 1988; 263: 2939-2947.

173. Bruns G, Stroh H, Veldman GM, Latt SA, Floros J. The $35 \mathrm{kD}$ pulmonary surfactant-associated protein is encoded on chromosome 10. Hum Genet 1987; 76: 58-62.

174. Fisher JH, Kao FT, Jones C, White RT, Benson BJ, Mason RJ. The coding sequence for the 32,000 dalton pulmonary surfactant-associated protein $\mathrm{A}$ is located on chromosome 10 and identifies two separate restrictionfragment-length polymorphisms. Am J Hum Genet 1987; 40: 503-511.

175. Ross GF, Notter RH, Meuth J, Whitsett JA. Phospholipid binding and biophysical activity of pulmonary surfactantassociated protein (SAP)-35 and its noncollagenous $\mathrm{COOH}-$ terminal domains. J Biol Chem 1986; 261: 14283-14291.

176. Ross GF, Meuth J, Ohning B, Kim Y, Whitsett JA. Purification of canine surfactant-associated glycoprotein A. Identification of a collagenase-resistant domain. Biochim Biophys Acta 1986; 870: 267-278.

177. Patthy L. Is lung surfactant protein a lectin-collagen hybrid? Nature 1987; 325: 490.

178. Drickamer K, Dordal MS, Reynolds L. Mannose-binding proteins isolated from rat liver contain carbohydraterecognition domains linked to collagenous tails. J Biol Chem 1986; 261: 6878-6887.

179. Haagsman HP, Hawgood S, Sargeant T, et al. The major lung surfactant protein, SP 28-36, is a calcium-dependent, carbohydrate-binding protein. J Biol Chem 1987; 262: 13877-13880

180. Haagsman HP, White RT, Schilling J, et al. Studies of the structure of lung surfactant protein SP-A. Am J Physiol 1989; 257: L421-L429.

181. Ross GF, Sawyer J, O'Connor T, Whitsett JA. Intermolecular cross-links mediate aggregation of phospholipid vesicles by pulmonary surfactant protein SP-A. Biochemistry 1991; 30: 858-865.

182. Crawford SW, Mecham RP, Sage H. Structural characteristics and intermolecular organization of human pulmonary-surfactant-associated proteins. Biochem $J$ 1986; 240: 107-114.

183. Ross GF, Ohning BL, Tannenbaum D, Whitsett JA. Structural relationships of the major glycoproteins from 
human alveolar proteinosis surfactant. Biochim Biophys Acta 1987; 911: 294-305.

184. Sastry K, Herman GA, Day L, et al. The human mannosebinding protein gene. Exon structure reveals its evolutionary relationship to a human pulmonary surfactant gene and localization to chromosome 10. J Exp Med 1989; 170: $1175-1189$.

185. Ezekowitz RAB. Anti-antibody immunity. Curr Biol 1991; 1: 60-62.

186. Ezekowitz RAB. Antigens coming to a sticky end. Curr Biol 1992; 2: 147-149.

187. King RJ, Simon D, Horowitz PM. Aspects of secondary and quarternary structure of surfactant protein A from canine lung. Biochim Biophys Acta 1989; 1001: 294 301.

188. Hawgood S, Haagsman HP. Surfactant-associated protein A. In: Ekelund L, Jonson B, Malm L, eds. Surfactant and the Respiratory Tract. Amsterdam, Elsevier, 1989; pp. $57-65$.

189. Voss T, Melchers K, Scheirle G, Schäfer KP. Structural comparison of recombinant pulmonary surfactant protein SP-A derived from two human coding sequences: implications for the chain composition of natural human SP-A. Am J Respir Cell Mol Biol 1991; 4: 88-94.

190. Spissinger T, Schäfer KP, Voss T. Assembly of the surfactant protein SP-A. Deletions in the globular domain interfere with the correct folding of the molecule. Eur J Biochem 1991; 199: 65-71.

191. Weis IW, Kahn R, Fourme R, Drickamer K, Hendrickson WA. Structure of the calcium-dependent lectin domain from a rat mannose-binding protein determined by MAD phasing. Science 1991; 254: 1608-1615.

192. King RJ. The surfactant system of the lung. Fed Proc 1974; 33: 2238-2247.

193. King RJ, Martin H, Mitts D, Holmstrom FM. Metabolism of the apoproteins in pulmonary surfactant. $J$ Appl Physiol 1977; 42: 483-491.

194. King RJ, Martin H. Intracellular metabolism of the apoproteins of pulmonary surfactant in rat lung. $J$ Appl Physiol 1980; 48: 812-820.

195. Crouch E, Rust K, Marienchek W, Parghi D, Chang D, Persson A. Developmental expression of pulmonary surfactant protein D (SP-D). Am J Respir Cell Mol Biol 1991; 5: 13-18.

196. Crouch E, Parghi D, Kuan SF, Persson A. Surfactant protein D: subcellular localization in nonciliated bronchiolar epithelial cells. Am J Physiol 1992; 263: L60-L66.

197. Persson A, Chang D, Rust K, Moxley M, Longmore W, Crouch E. Purification and biochemical characterization of CP4 (SP-D), a collagenous surfactant-associated protein. Biochemistry 1989; 28: 6361-6367.

198. Lim BL, Lu J, Reid KB. Structural similarity between bovine conglutinin and bovine lung surfactant protein $\mathrm{D}$ and demonstration of liver as a site of synthesis of conglutinin. Immunology 1993; 78: 159-165.

199. Holmskov U, Teisner B, Willis AC, Reid KBM, Jensenius JC. Purification and characterization of a bovine serum lectin (CL-43) with structural homology to conglutinin and SP-D and carbohydrate specificity similar to mannanbinding protein. J Biol Chem 1993; 268: 10120-10125.

200. Crouch E, Rust K, Veile R, Donis-Keller H, Grosso L. Genomic organization of human surfactant protein D (SPD). SP-D is encoded on chromosome 10q22.2-23.1. $J$ Biol Chem 1993; 268: 2976-2983.

201. Persson A, Chang D, Crouch E. Surfactant protein D is a divalent cation-dependent carbohydrate-binding protein. J Biol Chem 1990; 265: 5755-5760.
202. Kuroki Y, Shiratori M, Ogasawara Y, Tsuzuki A, Akino T. Characterization of pulmonary surfactant protein D: its copurification with lipids. Biochim Biophys Acta 1991; 1086: 185-190.

203. Persson AV, Gibbons BJ, Shoemaker JD, Moxley MA, Longmore WJ. The major glycolipid recognized by SP$\mathrm{D}$ in surfactant is phosphatidylinositol. Biochemistry 1992; 31: 12183-12189.

204. Ogasawara Y, Kuroki Y, Akino T. Pulmonary surfactant protein D specifically binds to phosphatidylinositol. $J$ Biol Chem 1992; 267: 21244-21249.

205. van Iwaarden JF, Shimizu H, van Golde PHM, Voelker DR, van Golde LMG. Rat surfactant protein D enhances the production of oxygen radicals by rat alveolar macrophages. Biochem J 1992; 286: 5-8.

206. Scarpelli EM, Chang SJ, Colacicco G. A search for the surface-active pulmonary lipoprotein. Am Rev Respir Dis 1970; 102: 285-289.

207. Whitsett JA, Ohning BL, Ross G, et al. Hydrophobic surfactant-associated protein in whole lung surfactant and its importance for biophysical activity in lung surfactant extracts used for replacement therapy. Pediatr Res 1986; 20: 460-467.

208. Yu SH, Chung W, Olafson RW, Harding PGR, Possmayer F. Characterization of the small hydrophobic proteins associated with pulmonary surfactant. Biochim Biophys Acta 1987; 921: 437-448.

209. Yu SH, Wallace D, Bhavnani B, Enhorning G, Harding PGR, Possmayer F. Effect of reconstituted pulmonary surfactant containing the 6,000 dalton hydrophobic protein on lung compliance of prematurely delivered rabbit fetuses. Pediatr Res 1988; 23: 23-30.

210. Whitsett JA, Hull WM, Ohning B, Ross G, Weaver TE. Immunologic identification of a pulmonary surfactantassociated protein of molecular weight 6,000 daltons. Pediatr Res 1986; 20: 744-749.

211. Phelps DS, Smith LM, Taeusch HW. Characterization and partial amino acid sequence of a low molecular weight surfactant protein. Am Rev Respir Dis 1987; 135: 11121117.

212. Olafson RW, Rink U, Kielland S, et al. Protein sequence analysis studies on the low molecular weight hydrophobic proteins associated with bovine pulmonary surfactant. Biochem Biophys Res Commun 1987; 148: 14061411.

213. Yu SH, Chung W, Possmayer F. Structural relationship between the two small hydrophobic apoproteins in bovine pulmonary surfactant. Biochim Biophys Acta 1989; 1005: 93-96.

214. Suzuki Y, Nakai E-I, Ohkawa K-I. Experimental studies on the pulmonary surfactant. Reconstitution of surfaceactive material. J Lipid Res 1982; 23: 53-61.

215. Suzuki Y, Curstedt T, Grossmann G, et al. The role of the low-molecular weight $(\leq 15,000$ daltons $)$ apoproteins of pulmonary surfactant. Eur J Respir Dis 1986; 69: 336-345.

216. Yu SH, Possmayer F. Reconstitution of surfactant activity by using the $6 \mathrm{kDa}$ apoprotein associated with pulmonary surfactant. Biochem J 1986; 236: 85-89.

217. Taeusch HW, Keough KMW, Williams M, et al. Characterization of bovine surfactant for infants with respiratory distress syndrome. Pediatrics 1986; 77 : 572-581.

218. Takahashi A, Fujiwara T. Proteolipid in bovine lung surfactant: its role in surfactant function. Biochem Biophys Res Commun 1986; 135: 527-532.

219. Hawgood S, Benson BJ, Schilling J, Damm D, Clements 
JA, White RT. Nucleotide and amino acid sequences of pulmonary surfactant protein SP 18 and evidence for cooperation between SP 18 and SP 28-36 in surfactant lipid adsorption. Proc Natl Acad Sci USA 1987; 84: 66-70.

220. Jacobs KA, Phelps DS, Steinbrink R, et al. Isolation of a cDNA clone encoding a high molecular weight precursor to a $6 \mathrm{kDa}$ pulmonary surfactant-associated protein. J Biol Chem 1987; 262: 9808-9811.

221. Glasser SW, Korfhagen TR, Weaver T, Pilot-Matias T, Fox JL, Whitsett JA. cDNA and deduced amino acid sequence of human pulmonary surfactant-associated proteolipid SPL (Phe). Proc Natl Acad Sci USA 1987; 84: 4007-4011.

222. Emrie PA, Shannon JM, Mason RJ, Fisher JH. cDNA and deduced amino acid sequence for the rat hydrophobic pulmonary surfactant-associated protein, SP-B. Biochim Biophys Acta 1989; 994: 215-221.

223. Xu J, Richardson C, Ford C, et al. Isolation and characterization of the cDNA for pulmonary surfactant-associated protein-B (SP-B) in the rabbit. Biochem Biophys Res Commun 1989; 160: 325-332.

224. Weaver TE, Sarin VK, Sawtell N, Hull WM, Whitsett JA. Identification of surfactant proteolipid SP-B in human surfactant and fetal lung. J Appl Physiol 1988; 65: 982-987.

225. O'Reilly MA, Weaver TE, Pilot-Matias TJ, Sarin VK, Gazdar AF, Whitsett JA. In vitro translation, posttranslational processing and secretion of pulmonary surfactant protein B precursors. Biochim Biophys Acta 1989; 1011: 140 148.

226. Warr RG, Hawgood S, Buckley DI, et al. Low molecular weight human pulmonary surfactant protein (SP5): isolation, characterization and cDNA and amino acid sequences. Proc Natl Acad Sci USA 1987; 84: 7915-7919.

227. Glasser SW, Korfhagen TR, Weaver TE, et al. cDNA, deduced polypeptide structure and chromosomal assignment of human pulmonary surfactant proteolipid, SPL (pVal). J Biol Chem 1988; 263: 9-12.

228. Fisher JH, Shannon JM, Hofmann T, Mason RJ. Nucleotide and deduced amino acid sequence of the hydrophobic surfactant protein SP-C from rat: expression in alveolar type II cells and homology with SP-C from other species. Biochim Biophys Acta 1989; 995: 225-230.

229. Keller A, Eistetter HR, Voss T, Schäfer KP. The pulmonary surfactant protein C (SP-C) precursor is a type II transmembrane protein. Biochem J 1991; 277: 493499.

230. Emrie PA, Jones C, Hofmann T, Fisher JH. The coding sequence for the human 18,000 dalton hydrophobic pulmonary surfactant protein is located on chromosome 2 and identifies a restriction fragment length polymorphism. Somat Cell Mol Genet 1988; 14: 105-110.

231. Pilot-Matias TJ, Kister SE, Fox JL, Kropp K, Glasser SW, Whitsett JA. Structure and organization of the gene encoding human pulmonary surfactant proteolipid SP-B. DNA 1989; 8: 75-86.

232. Glasser SW, Korfhagen TR, Perme CM, Pilot-Matias TJ, Kister SE, Whitsett JA. Two SP-C genes encoding human pulmonary surfactant proteolipid. J Biol Chem 1988; 263: 10326-10331.

233. Fisher JH, Emrie PA, Drabkin HA, et al. The gene encoding the hydrophobic surfactant protein SP-C is located on 8p and identifies an EcoRI RFLP. Am J Hum Genet 1988; 43: 436-441.

234. Jörnvall H. Microheterogeneity problems in protein sequence analysis. In: Walsh KA, ed. Methods in Protein
Sequence Analysis. New Jersey, Humana Press, 1986; pp. 323-333.

235. Pastrana B, Mautone AJ, Mendelsohn R. Fourier transform infra-red studies of secondary structure and orientation of pulmonary surfactant SP-C and its effect on the dynamic surface properties of phospholipids. Biochemistry 1991; 30: 10058-10064.

236. Vandenbussche G, Clercx A, Curstedt T, Johansson J, Jörnvall H, Ruysschaert JM. Structure and orientation of the surfactant-associated protein $\mathrm{C}$ in a lipid bilayer. Eur J Biochem 1992; 203: 201-209.

237. Vandenbussche G, Clercx A, Clercx M, et al. Secondary structure and orientation of the surfactant protein SP-B in a lipid environment. A Fourier transform infra-red spectroscopy study. Biochemistry 1992; 31: 9169-9176.

238. Baatz JE, Smyth KL, Whitsett JA, Baxter C, Absolom DR. Structure and functions of a dimeric form of surfactant protein SP-C: a Fourier transform infra-red and surfactometry study. Chem Phys Lipids 1992; 63: 91-104.

239. Morrow MR, Pérez-Gil J, Simatos G, et al. Pulmonary surfactant-associated protein SP-B has little effect on acyl chains in dipalmitoylphosphatidylcholine dispersions. Biochemistry 1993; 32: 4397-4402.

240. Sanders RL, Hassett RJ, Vatter AE. Isolation of lung lamellar bodies and their conversion to tubular myelin figures in vitro. Anat Rec 1980; 198: 485-501.

241. Benson BJ, Hawgood S, Williams MC. Role of apoprotein and calcium ions in surfactant function. Exp Lung Res 1984; 6: 223-236.

242. Benson BJ, Williams MC, Sueishi WK, Goerke J, Sargeant T. Role of calcium ions in the structure and function of pulmonary surfactant. Biochim Biophys Acta 1984; 793 : $18-27$.

243. Notter RH, Penney DP, Finkelstein JN, Shapiro DL. Adsorption of natural lung surfactant and phospholipid extracts related to tubular myelin formation. Pediatr Res 1986; 20: 97-101.

244. Efrati H, Hawgood S, Williams MC, Hong K, Benson BJ. Divalent cation and hydrogen ion effects on the structure and surface activity of pulmonary surfactant. Biochemistry 1987; 26: 7986-7993.

245. Suzuki Y, Fujita Y, Kogishi K. Reconstitution of tubular myelin from synthetic lipids and proteins associated with pig pulmonary surfactant. Am Rev Respir Dis 1989; 140: $75-81$.

246. Williams MC, Hawgood S, Hamilton RL. Changes in lipid structure produced by surfactant proteins SP-A, SPB, and SP-C. Am J Respir Cell Mol Biol 1991; 5: 4150 .

247. Berggren P, Curstedt T, Grossmann G, Nilsson R, Robertson B. Physiological activity of pulmonary surfactant with low protein content: effect of enrichment with synthetic phospholipids. Exp Lung Res 1985; 8: 29-51.

248. Notter RH, Shapiro DL, Ohning B, Whitsett JA. Biophysical activity of synthetic phospholipids combined with purified lung surfactant 6,000 dalton apoprotein. Chem Phys Lipids 1987; 44: 1-17.

249. Smith GB, Taeusch HW, Phelps DS, Keough KMW. Mixtures of low molecular weight surfactant proteins and dipalmitoyl phosphatidylcholine duplicate effects of pulmonary surfactant in vitro and in vivo. Pediatr Res 1988; 23: 484-490.

250. Yamada T, Ikegami M, Tabor BL, Jobe AH. Effects of surfactant protein-A on surfactant function in preterm ventilated rabbits. Am Rev Respir Dis 1990; 142: 754-757.

251. Oosterlaken-Dijksterhuis MA, Haagsman HP, van Golde LMG, Demel RA. Interaction of lipid vesicles with 
monomolecular layers containing lung surfactant proteins SP-B or SP-C. Biochemistry 1991; 30: 8276-8281.

252. Oosterlaken-Dijksterhuis MA, Haagsman HP, van Golde LMG, Demel RA. Characterization of lipid insertion into monomolecular layers mediated by lung surfactant proteins SP-B and SP-C. Biochemistry 1991; 30: 10965-10971.

253. Suzuki Y, Robertson B, Fujita Y, Grossmann G. Respiratory failure in mice caused by a hybridoma making antibodies to the $15 \mathrm{kDa}$ surfactant apoprotein. Acta Anaesthesiol Scand 1988; 32: 283-289.

254. Fujita Y, Kogishi K, Suzuki Y. Pulmonary damage induced in mice by a monoclonal antibody to proteins associated with pig pulmonary surfactant. Exp Lung Res 1988; 14: 247-260.

255. Robertson B, Kobayashi T, Ganzuka M, Grossmann G, Li WZ, Suzuki Y. Experimental neonatal respiratory failure induced by a monoclonal antibody to the hydrophobic surfactant-associated protein SP-B. Pediatr Res 1991; 30: 239-243.

256. Baatz JE, Sarin V, Absolom DR, Baxter C, Whitsett JA. Effects of surfactant-associated protein SP-B synthetic analogs on the structure and surface activity of model membrane bilayers. Chem Phys Lipids 1991; 60: 163178.

257. Revak SD, Merritt TA, Hallman M, et al. The use of synthetic peptides in the formation of biophysically and biologically active pulmonary surfactants. Pediatr Res 1991; 29: 460-465.

258. Cochrane CG, Revak SD. Pulmonary surfactant protein B (SP-B): structure-function relationships. Science 1991; 254: 566-568.

259. Fan BR, Bruni R, Taeusch HW, Findlay R, Waring AJ. Antibodies against synthetic amphipathic helical sequences of surfactant protein SP-B detect a conformational change in the native protein. FEBS Lett 1991; 282: 220-224.

260. Bruni R, Taeusch HW, Waring AJ. Surfactant protein B: lipid interactions of synthetic peptides representing the amino-terminal amphipathic domain. Proc Natl Acad Sci USA 1991; 88: 7451-7455.

261. McLean LR, Lewis JE, Hagaman KA, Owen TJ, Jackson RL. Amphipathic $\alpha$-helical peptides based on surfactant apoprotein SP-A. Biochim Biophys Acta 1993; 1166 : 31-38.

262. McLean LR, Lewis JE, Krstenansky JL, et al. An amphipathic $\alpha$-helical decapeptide in phosphatidylcholine is an effective synthetic lung surfactant. Am Rev Respir Dis 1993; 147: 462-465.

263. Venkitaraman AR, Hall SB, Notter RH. Hydrophobic homopolymeric peptides enhance the biophysical activity of synthetic lung phospholipids. Chem Phys Lipids 1990; 53: $157-164$.

264. Spragg RG, Gilliard N, Richman P, et al. The adult respiratory distress syndrome: clinical aspects relevant to surfactant supplementation. In: Robertson B, van Golde LMG, Batenburg JJ, eds. Pulmonary Surfactant: From Molecular Biology to Clinical Practice. Elsevier, Amsterdam, 1992; pp. 685-703.

265. Seeger W, Stöhr G, Wolf HRD, Neuhof H. Alteration of surfactant function due to protein leakage: special interaction with fibrin monomer. J Appl Physiol 1985; 58; 326-338.

266. Cockshutt AM, Weitz J, Possmayer F. Pulmonary surfactant-associated protein A enhances the surface activity of lipid extract surfactant and reverses inhibition by blood proteins in vitro. Biochemistry 1990; 29: 8424-8429.
267. Seeger W, Thede C, Günther A, Grube C. Surface properties and sensitivity to protein-inhibition of a recombinant apoprotein C-based phospholipid mixture in vitro: comparison to natural surfactant. Biochim Biophys Acta 1991; 1081: 45-52.

268. Holm BA, Venkitaraman AR, Enhorning G, Notter RH. Biophysical inhibition of synthetic lung surfactants. Chem Phys Lipids 1990; 52: 243-250.

269. Bach R, Konigsberg WH, Nemerson Y. Human tissue factor contains thioester-linked palmitate and stearate on the cytoplasmic half-cystine. Biochemistry 1988; 27: 4227-4231.

270. Ovchinnikov YA, Abdulaev NG, Bogachuk AS. Two adjacent cysteine residues in the C-terminal cytoplasmic fragment of bovine rhodopsin are palmitylated. FEBS Lett 1988; 230: 1-5.

271. Magee T, Hanley M. Sticky fingers and CAAX boxes. Nature 1988; 335: 114-115.

272. Sudo Y, Valenzuela D, Beck-Sickinger AG, Fishman MC, Strittmatter SM. Palmitoylation alters protein activity: blockade of $\mathrm{G}_{0}$ stimulation by GAP-43. EMBO J 1992; 11: 2095-2102.

273. Omary MB, Trowbridge IS. Biosynthesis of the human transferrin receptor in cultured cells. J Biol Chem 1981; 256: $12888-12892$.

274. Heath MF, Jacobson W. Phospholipase $A_{1}$ and $A_{2}$ in lamellar inclusion bodies of the alveolar epithelium of rabbit lung. Biochim Biophys Acta 1976; 441: 443452.

275. Lecerf J, Fouilland L, Gagniarre J. Evidence for a high activity of sphingomyelin biosynthesis by phosphocholine transfer from phosphatidylcholine to ceramides in lung lamellar bodies. Biochim Biophys Acta 1987; 918: 4859.

276. Sefton BM, Buss JE. The covalent modification of eukaryotic proteins with lipid. J Cell Biol 1987; 104: 1449-1453.

277. Reilly KE, Mautone AJ, Mendelsohn R. Fourier-transform infra-red spectroscopy studies of lipid/protein interaction in pulmonary surfactant. Biochemistry 1989; 28: 73687373.

278. Shiffer K, Hawgood S, Düzgünes N, Goerke J. Interactions of the low molecular weight group of surfactant-associated proteins (SP 5-18) with pulmonary surfactant lipids. Biochemistry 1988; 27: 2689-2695.

279. Simatos GA, Forward KB, Morrow MR, Keough KMW. Interaction between perdeuterated dimyristoyl-phosphatidylcholine and low molecular weight pulmonary surfactant protein SP-C. Biochemistry 1990; 29: 5807-5814.

280. Horowitz AD, Elledge B, Whitsett JA, Baatz JE. Effects of lung surfactant proteolipid SP-C on the organization of model membrane lipids: a fluorescence study. Biochim Biophys Acta 1992; 1107: 44-54.

281. Baatz JE, Elledge B, Whitsett JA. Surfactant protein SP$B$ induces ordering at the surface of model membrane bilayers. Biochemistry 1990; 29: 6714-6720.

282. Patthy L. Homology of the precursor of pulmonary surfactant-associated protein SP-B with prosaposin and sulfated glycoprotein 1. J Biol Chem 1991; 266: 6035-6037.

283. Gross NJ, Schultz RM. Serine proteinase requirement for the extracellular metabolism of pulmonary surfactant. Biochim Biophys Acta 1990; 1044: 222-230.

284. Gross NJ, Schultz RM. Requirements of extracellular metabolism of pulmonary surfactant: tentative identification of serine protease. Am J Physiol 1992; 262: L446-L453.

285. McLean LR, Hagaman KA, Owen TJ, Krstenansky JL. Minimal peptide length for interaction of amphipathic 
$\alpha$-helical peptides with phosphatidylcholine liposomes. Biochemistry 1991; 30: 31-37.

286. Auten RL, Notter RH, Kendig JW, Davis JM, Shapiro DL. Surfactant treatment of full-term newborns with respiratory failure. Pediatrics 1991; 87: 101-107.

287. Shapiro DL, Notter RH, Morin III FC, et al. Doubleblind, randomized trial of a calf lung surfactant extract administered at birth to very premature infants for prevention of respiratory distress syndrome. Pediatrics 1985; 76 : 593-599.

288. Gortner L, Pohlandt F, Weller E. Effects of bovine surfactant in premature lambs after intratracheal application. Eur J Pediatr 1990; 149: 280-283.

289. Robertson B, Curstedt T, Johansson J, Jörnvall H, Kobayashi T. Structural and functional characterization of porcine surfactant isolated by liquid-gel chromatography. Prog Respir Res 1990; 25: 237-246.

290. Collaborative European Multicentre Study Group. Factors influencing the clinical response to surfactant replacement therapy in babies with severe respiratory distress syndrome. Eur J Pediatr 1991; 150: 433-439.

291. Speer CP, Robertson B, Curstedt T, et al. Randomized European multicenter trial of surfactant replacement therapy for severe neonatal respiratory distress syndrome; single versus multiple doses of Curosurf. Pediatrics 1992; 89: 13-20.

292. Fujiwara T, Robertson B. Pharmacology of exogenous surfactant. In: Robertson B, van Golde LMG, Batenburg JJ, eds. Pulmonary Surfactant: From Molecular Biology to Clinical Practice. Amsterdam, Elsevier, 1992; pp. 561-592.

293. Hallman M, Merritt TA, Schneider H. Isolation of human surfactant from amniotic fluid and a pilot study of its efficacy in respiratory distress syndrome. Pediatrics 1983; 71: 473-482.

294. Jobe A, Ikegami M. Surfactant for the treatment of respiratory distress syndrome. Am Rev Respir Dis 1987; 136: $1256-1275$.

295. Morley CJ, Greenough A, Miller NG, et al. Randomized trial of artificial surfactant (ALEC) given at birth to babies from 23 to 34 weeks gestation. Early Hum Dev 1988; 17: 41-54.

296. Morley CJ, Bangham AD, Miller N, Davis JA. Dry artificiàl lung surfactant and its effect on very premature babies. Lancet 1981; 1: 64-68.

297. Morley CJ, Robertson B, Lachmann B, et al. Artificial surfactant and natural surfactant. Comparative study of the effects on premature rabbit lungs. Arch Dis Child 1980; 55: 758-765.

298. Egan EA, Notter RH, Kwong MS, Shapiro DL. Natural and artificial lung surfactant replacement therapy in premature lambs. J Appl Physiol 1983; 55: 875-883.

299. Greenough A, Morley CJ, Wood S, Miller N, Bangham AD. Effect of artificial surfactant on lung function of preterm neonates. Prog Respir Res 1984; 18: 263-266.

300. Ten Centre Study Group. Ten centre trial of artificial surfactant (artificial lung expanding compound) in very premature babies. Br Med J 1987; 294: 991-996.

301. Morley CJ, Greenough A. Respiratory compliance in premature babies treated with artificial surfactant (ALEC). Arch Dis Child 1991; 66: 467-471.

302. Tooley WH, Clements JA, Muramatsu K, Brown CL, Schlueter MA. Lung function in prematurely delivered rabbits treated with a synthetic surfactant. Am Rev Respir Dis 1978; 136: 347-351.

303. Hall SB, Venkitaraman AR, Whitsett JA, Holm BA, Notter RH. Importance of hydrophobic apoproteins as constituents of clinical exogenous surfactants. Am Rev Respir Dis 1992; 145: 24-30.

304. Durand DJ, Clyman RI, Heymann MA, et al. Effects of a protein-free, synthetic surfactant on survival and pulmon-ary function in preterm lambs. J Pediatr 1985; 107: 775-780.

305. Long W, Thompson T, Sundell H, et al. Effects of two rescue doses of a synthetic surfactant on mortality rate and survival without bronchopulmonary dysplasia in 700-1,350 g infants with respiratory distress syndrome. J Pediatr 1991; 118: 595-605.

306. Venkitaraman AR, Baatz JE, Whitsett JA, Hall SB, Notter RH. Biophysical inhibition of synthetic phospholipidlung surfactant apoprotein admixtures by plasma proteins. Chem Phys Lipids 1991; 57: 49-57.

307. van Iwaarden JF, van Strijp JAG, Ebskamp MJM, Welmers AC, Verhoef J, van Golde LMG. Surfactant protein A is opsonin in phagocytosis of herpes simplex virus type 1 by rat alveolar macrophages. Am J Physiol 1991; 261: L204-L209.

308. Sherman MP, Campbell LA, Merritt TA, Shapiro DL, Long WA, Gunkel JH. The infected preterm rabbit lung. A model to test the effect of surfactant replacement on lung host defenses. Prog Respir Res 1990; 25: 204-208.

309. Tanaka Y, Takei T, Aiba T, Masuda K, Kiuchi A, Fujiwara T. Development of synthetic lung surfactants. J Lipid Res 1986; 27: 475-485. 